Journal for ImmunoTherapy of Cancer

\title{
Prognostic significance of myeloid immune cells and their spatial distribution in the colorectal cancer microenvironment
}

\author{
Juha P Väyrynen (D) , ${ }^{1,2,3}$ Koichiro Haruki, ${ }^{2,3,4}$ Sara A Väyrynen, ${ }^{2}$ Mai Chan Lau, ${ }^{3}$ \\ Andressa Dias Costa, ${ }^{2}$ Jennifer Borowsky, ${ }^{5}$ Melissa Zhao, ${ }^{3}$ Tomotaka Ugai, ${ }^{3,6}$ \\ Junko Kishikawa, ${ }^{3}$ Naohiko Akimoto, ${ }^{3}$ Rong Zhong, ${ }^{3}$ Shanshan Shi, ${ }^{3}$ \\ Tzuu-Wang Chang, ${ }^{3}$ Kenji Fujiyoshi, ${ }^{3}$ Kota Arima, ${ }^{3}$ Tyler S Twombly, ${ }^{3}$ \\ Annacarolina Da Silva, ${ }^{3}$ Mingyang Song, ${ }^{7,8,9}$ Kana Wu,,${ }^{6,7,10}$ Xuehong Zhang, ${ }^{10}$ \\ Andrew T Chan, ${ }^{8,9,10,11}$ Reiko Nishihara, ${ }^{3,6,7,12}$ Charles S Fuchs, ${ }^{13,14,15}$ \\ Jeffrey A Meyerhardt, ${ }^{2}$ Marios Giannakis, ${ }^{2,16,17}$ Shuji Ogino, ${ }^{3,6,16,18}$ \\ Jonathan A Nowak (i) ${ }^{3}$
}

To cite: Väyrynen JP, Haruki K, Väyrynen SA, et al. Prognostic significance of myeloid immune cells and their spatial distribution in the colorectal cancer microenvironment. Journal for ImmunoTherapy of Cancer 2021;9:e002297. doi:10.1136/jitc-2020-002297

JPV, KH, SAV and MCL are joint first authors.

JAM, MG, SO and JAN are joint senior authors.

Accepted 18 March 2021

Check for updates

(c) Author(s) (or their employer(s)) 2021. Re-use permitted under CC BY-NC. No commercial re-use. See rights and permissions. Published by BMJ.

For numbered affiliations see end of article.

\section{Correspondence to} Dr Jonathan A Nowak; janowak@bwh.harvard.edu

Dr Shuji Ogino; sogino@bwh.harvard.edu

\section{ABSTRACT}

Background Myeloid cells represent an abundant yet heterogeneous cell population in the colorectal cancer microenvironment, and their roles remain poorly understood.

Methods We used multiplexed immunofluorescence combined with digital image analysis to identify $\mathrm{CD} 14^{+}$ monocytic and $\mathrm{CD}_{15}{ }^{+}$granulocytic cells and to evaluate their maturity (HLA-DR and CD33), immunosuppressive potential (ARG1) and proximity to cytokeratin (KRT)positive tumor cells in 913 colorectal carcinomas. Using covariate data of 4465 incident colorectal cancers in two prospective cohort studies, the inverse probability weighting method was used with multivariable-adjusted Cox proportional hazards models to assess cancer-specific mortality according to ordinal quartiles (Q1-Q4) of myeloid cell densities. Immune cell-tumor cell proximity was measured with the nearest neighbor method and the G-cross function, which determines the likelihood of any tumor cell having at least one immune cell of the specified type within a certain radius.

Results Higher intraepithelial $\left(P_{\text {trend }}=0.0002\right.$; HR for Q4 (vs Q1), $0.48,95 \% \mathrm{Cl} 0.31$ to 0.76 ) and stromal $\left(P_{\text {trend }}<0.0001\right.$; HR for Q4 (vs Q1), $0.42,95 \% \mathrm{Cl} 0.29$ to $0.63)$ densities of $\mathrm{CD}_{14}{ }^{+} \mathrm{HLA}-\mathrm{DR}^{+}$cells were associated with lower colorectal cancer-specific mortality while, conversely, higher intraepithelial densities of CD14 ${ }^{+} \mathrm{HLA}$ $\mathrm{DR}^{-}$cells were associated with higher colorectal cancerspecific mortality $\left(P_{\text {trend }}=0.0003\right.$; HR for Q4 (vs Q1), $1.78,95 \% \mathrm{Cl} 1.25$ to 2.55$)$. Spatial analyses indicated that $\mathrm{CD}^{+} 5^{+}$cells were located closer to tumor cells than $\mathrm{CD}_{14}{ }^{+}$cells, and $\mathrm{CD} 14^{+} \mathrm{HLA}-\mathrm{DR}^{+}$cells were closer to tumor than $\mathrm{CD}^{+} 4^{+} \mathrm{HLA}^{-D R^{-}}$cells $(p<0.0001)$. The G-cross proximity measurement, evaluating the difference in the likelihood of any tumor cell being colocated with at least one $\mathrm{CD}_{14}{ }^{+} \mathrm{HLA}-\mathrm{DR}^{+}$cell versus $\mathrm{CD} 14^{+} \mathrm{HLA}-\mathrm{DR}^{-}$cell within a $20 \mu \mathrm{m}$ radius, was associated with lower colorectal cancer-specific mortality $\left(P_{\text {trend }}<0.0001\right.$; HR for Q4 (vs Q1), $0.37,95 \% \mathrm{Cl} 0.24$ to 0.57 ).

Conclusions Myeloid cell populations occur in spatially distinct distributions and exhibit divergent, subset-specific prognostic significance in colorectal cancer, with mature

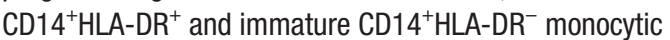
phenotypes most notably showing opposite associations. These results highlight the prognostic utility of multimarker evaluation of myeloid cell infiltrates and reveal a previously unrecognized degree of spatial organization for myeloid cells in the immune microenvironment.

\section{BACKGROUND}

Colorectal cancer is the second most common cause of cancer deaths in the world. ${ }^{1}$ A substantial fraction of cells present in the colorectal cancer microenvironment are derived from myeloid progenitor cells in the bone marrow. ${ }^{2}$ These cells are heterogenous, can exhibit functional and phenotypic plasticity and may exert protumorigenic and antitumorigenic effects. ${ }^{23}$ Analyses incorporating this diversity may advance the understanding of colorectal cancer biology and facilitate the development of improved tumor-immune biomarkers and cancer therapies.

In the late 1990s and early 2000s, it was established that cancer might cause aberrant, sustained myelopoiesis resulting in the accumulation of immature myeloid cells in the circulation and peripheral tissues ${ }^{4-6}$; such cells were subsequently termed myeloidderived suppressor cells (MDSCs) in recognition of their high potential to suppress immune responses. ${ }^{7}$ Myeloid cells comprise CD $14^{+}$monocytic cells (such as monocytes and macrophages) and $\mathrm{CD} 15^{+}$granulocytic cells (such as neutrophils and eosinophils), and accordingly, the major human MDSC subgroups include CD14 ${ }^{+}$monocytic MDSCs and $\mathrm{CD}_{15} 5^{+}$polymorphonuclear MDSCs. ${ }^{6}$ 
Accurate identification of specific myeloid cell subsets requires a combination of multiple markers, which has been possible with multiparameter flow cytometry. ${ }^{6}$ Recent developments in multiplex immunofluorescence have enabled simultaneous detection of multiple antigens in situ with single cell resolution. ${ }^{8}$ However, these methods have not yet been used to analyze immune cells in the colorectal cancer microenvironment, where most such analyses have been conducted using traditional immunohistochemistry. ${ }^{29}$

In this study, we used multiplex immunofluorescence combined with digital image analysis and machine learning to identify $\mathrm{CD} 14^{+}$monocytic and $\mathrm{CD} 15^{+}$granulocytic myeloid cells and to evaluate their maturity (HLA-DR and CD33), suppressive potential (arginase 1 (ARG1)), ${ }^{10}$ and proximity to cytokeratin (KRT)-positive tumor cells in 913 colorectal cancers in two US nationwide prospective cohort studies. As our primary aim, using 4465 incident colorectal cancer cases and the inverse probability weighting (IPW) method to adjust for selection bias, we analyzed the prognostic significance of different myeloid cell populations within tumor tissue. As our secondary aim, we characterized the spatial patterns of different myeloid infiltrates and their prognostic significance, as well as the relationships of myeloid infiltrates with tumor molecular features.

\section{METHODS \\ Study population}

The study was based on two prospective cohort studies, the Nurses' Health Study (NHS; 121701 women followed since 1976) and the Health Professionals Follow-up Study (HPFS; 51529 men followed since 1986), where 4465 incident colorectal cancer cases had occurred and were documented until 2012. We included both colon and rectal carcinoma cases, based on the colorectal continuum model, ${ }^{11}$ and analyzed myeloid cell densities in 913 cases, based on the availability of adequate tissue specimens (table 1, online supplemental figure S1). All participants gave informed consent for the study.

Blinded to exposure data, study physicians reviewed the medical records related to colorectal cancer and collected clinical information such as the American Joint Committee on Cancer tumor, node, metastases stage and tumor location. Deaths and unreported lethal colorectal cancer cases were identified using the National Death Index, and cause of death was also recorded. Survival time was defined as the period from the date of colorectal cancer diagnosis to death or the end of follow-up (January 1, 2016 for HPFS; June 1, 2016 for NHS). For analyses of colorectal cancer specific mortality, deaths as a result of other causes were censored.

Formalin-fixed paraffin-embedded (FFPE) tissue blocks were collected, and DNA was extracted using the QIAmp DNA Mini Kit (Qiagen, Valencia, California, USA). ${ }^{12}$ Microsatellite instability (MSI) status was analyzed with 10 microsatellite markers (BAT25, BAT26, BAT40,
D2S123，D5S346，D17S250，D18S55，D18S56，D18S67, and D18S487), as previously described. ${ }^{13}$ Methylation analyses for eight promoters specific for the $\mathrm{CpG}$ island methylator phenotype (CIMP; CACNA1G, CDKN2A, CRABP1, IGF2, MLH1, NEUROG1, RUNX3, and SOCS1) were conducted using bisulfite-treated DNA and realtime PCR, ${ }^{13}$ and long interspersed nucleotide element-1 (LINE-1) methylation level was assessed with pyrosequencing. ${ }^{14}$ Pyrosequencing was performed to evaluate $B R A F$ (codon 600), KRAS (codons 12, 13, 61 and 146) and PIK3CA (exons 9 and 20) mutation status. ${ }^{15}$ Neoantigen load of 412 tumors was estimated using a neoantigen prediction pipeline for somatic mutations based on whole-exome sequencing and identifying peptides binding to human leukocyte antigen (MHC) molecules with high affinity. ${ }^{16}$ One pathologist $(\mathrm{SO})$ reviewed H\&Estained tissue sections to confirm the diagnoses and evaluate tumor differentiation (well/moderate vs poor) and lymphocytic reaction patterns (tumor-infiltrating lymphocytes; intratumoral periglandular reaction; peritumoral reaction; and Crohn's-like lymphoid reaction). ${ }^{17}$ Tissue microarrays (TMAs) containing 1-4 (median 2) $0.6 \mathrm{~mm}$ diameter cores from representative areas of each tumor were constructed. ${ }^{18}$ Densities of granulocytic cells (neutrophils and eosinophils) from 900 tumors were evaluated from H\&E-stained TMA sections using a computerassisted method, as previously described. ${ }^{19}$

\section{Multiplex immunofluorescence}

We built a multiplex immunofluorescence assay, incorporating tyramide signal amplification for high antigen sensitivity, ${ }^{20}$ to evaluate myeloid cells in the colorectal cancer microenvironment. First, we screened potential markers and antibody clones based on published literature. ${ }^{621-27}$ Candidate antibody testing was then performed on colorectal cancer tissue and lymphoid controls via chromogenic immunohistochemistry, and antibody clones with expression patterns corresponding to their biologically expected distribution (at both the tissue level and subcellular level) were selected for further testing via immunofluorescence. Antibody clones with the highest signal-to-noise ratio were then compiled into a multiplex immunofluorescence panel containing a monocytic lineage marker (CD14), a granulocytic lineage marker (CD15), a macrophage maturity marker (HLA-DR), a myeloid cell immaturity marker (CD33), a suppressive marker (ARG1), and a tumor epithelial cell marker (KRT, keratins), following standardized protein nomenclature recommended by a panel of experts ${ }^{28}$ (online supplemental figure S2). Antibody and fluorophore concentrations and antibody-fluorophore pairing were then iteratively optimized, and similar staining patterns between chromogenic immunohistochemistry and multiplex immunofluorescence were confirmed (online supplemental figure S3). The final immunofluorescence protocol was automated with a Leica Bond RX Research Stainer (Leica Biosystems, Buffalo, Illinois, USA) (online supplemental figure $\mathrm{S} 2$ ). 
Table 1 Clinical, pathological and molecular characteristics of colorectal cancer cases according to CD14 ${ }^{+}$cell and CD15 $5^{+}$ cell densities

\begin{tabular}{|c|c|c|c|c|c|c|c|c|c|}
\hline \multirow[b]{2}{*}{ Characteristic* $^{\star}$} & \multirow[b]{2}{*}{$\begin{array}{l}\text { All cases } \\
(\mathrm{N}=913)\end{array}$} & \multicolumn{4}{|c|}{ Overall CD14 ${ }^{+}$cell density } & \multicolumn{4}{|c|}{ Overall CD15 ${ }^{+}$cell density } \\
\hline & & $\begin{array}{l}\text { Q1 (lowest) } \\
\text { ( } \mathrm{N}=228)\end{array}$ & $\begin{array}{l}\text { Q2 } \\
(\mathrm{N}=228)\end{array}$ & $\begin{array}{l}\text { Q3 } \\
\text { (N=229) }\end{array}$ & $\begin{array}{l}\text { Q4 (highest) } \\
\text { ( } \mathrm{N}=228)\end{array}$ & $\begin{array}{l}\text { Q1 (lowest) } \\
\text { (N=228) }\end{array}$ & $\begin{array}{l}\text { Q2 } \\
(\mathrm{N}=228)\end{array}$ & $\begin{array}{l}\text { Q3 } \\
\text { (N=229) }\end{array}$ & $\begin{array}{l}\text { Q4 (highest) } \\
\text { (N=228) }\end{array}$ \\
\hline \multicolumn{10}{|l|}{ Sex, n (\%) } \\
\hline Female (NHS) & $505(55)$ & $128(56)$ & $131(57)$ & $121(53)$ & $125(55)$ & $122(54)$ & $119(52)$ & $135(59)$ & $129(57)$ \\
\hline Male (HPFS) & $408(45)$ & $100(44)$ & $97(43)$ & $108(47)$ & $103(45)$ & $106(46)$ & $109(48)$ & $94(41)$ & $99(43)$ \\
\hline Mean age $\pm S D$ (years) & $68.8 \pm 8.9$ & $68.2 \pm 8.8$ & $69.0 \pm 8.7$ & $68.6 \pm 9.1$ & $69.7 \pm 8.9$ & $67.7 \pm 9.3$ & $69.2 \pm 8.7$ & $68.9 \pm 8.9$ & $69.6 \pm 8.7$ \\
\hline 1995 or before & $301(33)$ & $85(37)$ & $72(32)$ & $76(33)$ & $68(30)$ & $80(35)$ & $74(32)$ & $85(37)$ & $62(27)$ \\
\hline $1996-2000$ & $299(33)$ & $72(32)$ & $76(33)$ & $76(33)$ & $75(33)$ & $75(33)$ & $79(35)$ & $72(31)$ & $73(32)$ \\
\hline $2001-2008$ & $313(34)$ & $71(31)$ & $80(35)$ & $77(34)$ & $85(37)$ & $73(32)$ & $75(33)$ & $72(31)$ & $93(41)$ \\
\hline \multicolumn{10}{|c|}{ Family history of colorectal cancer in first-degree relative(s), $\mathrm{n}(\%)$} \\
\hline Absent & $720(79)$ & $181(80)$ & $183(81)$ & $185(81)$ & $171(76)$ & $174(77)$ & $184(81)$ & $178(78)$ & $184(81)$ \\
\hline Ascending to transverse colon & $298(33)$ & $78(34)$ & $75(33)$ & $71(31)$ & $74(33)$ & $64(28)$ & $79(35)$ & $72(32)$ & $83(36)$ \\
\hline Descending to sigmoid colon & $272(30)$ & $71(31)$ & $69(30)$ & $69(30)$ & $63(28)$ & $82(36)$ & $64(28)$ & $75(33)$ & $51(22)$ \\
\hline Rectum & $178(20)$ & $45(20)$ & $53(23)$ & $41(18)$ & $41(18)$ & $42(19)$ & $52(23)$ & $44(19)$ & $42(18)$ \\
\hline \multicolumn{10}{|l|}{ AJCC disease stage, $n(\%)$} \\
\hline 1 & $193(23)$ & $44(20)$ & $47(22)$ & $52(24)$ & $50(24)$ & $40(19)$ & $45(21)$ & $55(26)$ & $53(24)$ \\
\hline$\|$ & $283(33)$ & $67(31)$ & $65(31)$ & $69(32)$ & $82(39)$ & $66(31)$ & $71(34)$ & $73(35)$ & $73(34)$ \\
\hline III & $245(29)$ & $66(30)$ & $64(30)$ & $59(28)$ & $56(27)$ & $64(30)$ & $62(30)$ & $54(26)$ & $65(30)$ \\
\hline IV & $130(15)$ & $41(19)$ & $36(17)$ & $33(15)$ & $20(9.6)$ & $43(20)$ & $32(15)$ & $29(14)$ & $26(12)$ \\
\hline \multicolumn{10}{|l|}{ Tumor differentiation, $\mathrm{n}(\%)$} \\
\hline Well to moderate & $824(90)$ & $212(93)$ & $215(94)$ & $204(89)$ & $193(85)$ & $209(92)$ & $212(93)$ & $211(92)$ & $192(84)$ \\
\hline High & 159 (19) & $29(13)$ & $27(13)$ & $48(23)$ & $55(27)$ & $22(10)$ & $32(15)$ & $41(19)$ & $64(30)$ \\
\hline $\begin{array}{l}\text { Mean LINE-1 methylation level } \pm \text { SD } \\
(\%)\end{array}$ & $62.5 \pm 9.5$ & $61.5 \pm 9.6$ & $61.6 \pm 9.7$ & $62.5 \pm 9.5$ & $64.5 \pm 9.1$ & $61.1 \pm 9.8$ & $61.5 \pm 9.5$ & $62.8 \pm 9.6$ & $64.8 \pm 8.9$ \\
\hline \multicolumn{10}{|l|}{ KRAS mutation, $\mathrm{n}(\%)$} \\
\hline Wild-type & $530(60)$ & $121(54)$ & $134(61)$ & $127(57)$ & $148(67)$ & $129(58)$ & $128(57)$ & $135(62)$ & $138(63)$ \\
\hline Mutant & $356(40)$ & $102(46)$ & $87(39)$ & $94(43)$ & $73(33)$ & $93(42)$ & $98(43)$ & $84(38)$ & $81(37)$ \\
\hline \multicolumn{10}{|l|}{ BRAF mutation, $\mathrm{n}(\%)$} \\
\hline Wild-type & $757(85)$ & $192(86)$ & $196(87)$ & $181(81)$ & $188(85)$ & $194(86)$ & $198(89)$ & $192(86)$ & $173(78)$ \\
\hline Mutant & $136(15)$ & $32(14)$ & $28(13)$ & $43(19)$ & $33(15)$ & $31(14)$ & $24(11)$ & $31(14)$ & $50(22)$ \\
\hline \multicolumn{10}{|l|}{ PIK3CA mutation, $\mathrm{n}(\%)$} \\
\hline Wild-type & $698(84)$ & $179(84)$ & $173(85)$ & $182(86)$ & $164(80)$ & $187(89)$ & $171(81)$ & $175(86)$ & $165(79)$ \\
\hline Mutant & $136(16)$ & $35(16)$ & $30(15)$ & $29(14)$ & $42(20)$ & $24(11)$ & $41(19)$ & $28(14)$ & $43(21)$ \\
\hline \multicolumn{10}{|l|}{ Neoantigen load, $n(\%)$} \\
\hline Q1 (lowest) & $103(25)$ & $30(29)$ & $22(21)$ & $25(24)$ & $26(25)$ & $28(27)$ & $25(24)$ & $29(28)$ & $21(20)$ \\
\hline Q2 & $103(25)$ & $29(28)$ & $33(32)$ & $23(22)$ & $18(17)$ & $30(29)$ & $25(24)$ & $24(23)$ & $24(23)$ \\
\hline Q3 & $103(25)$ & $23(22)$ & $22(21)$ & $32(31)$ & $26(25)$ & $27(26)$ & $27(26)$ & $22(21)$ & $27(26)$ \\
\hline Q4 (highest) & $103(25)$ & $21(20)$ & $26(25)$ & $23(22)$ & 33 (32) & $18(17)$ & $26(25)$ & $28(27)$ & $31(30)$ \\
\hline
\end{tabular}

*Percentage indicates the proportion of patients with a specific clinical, pathologic or molecular characteristic among all patients or in strata of myeloid cell density.

AJCC, American Joint Committee on Cancer; CIMP, CpG island methylator phenotype; HPFS, Health Professionals Follow-up Study; LINE-1, long-interspersed nucleotide element-1; MSI, microsatellite instability; NHS, Nurses' Health Study.; 
A Multiplex immunofluorescence image
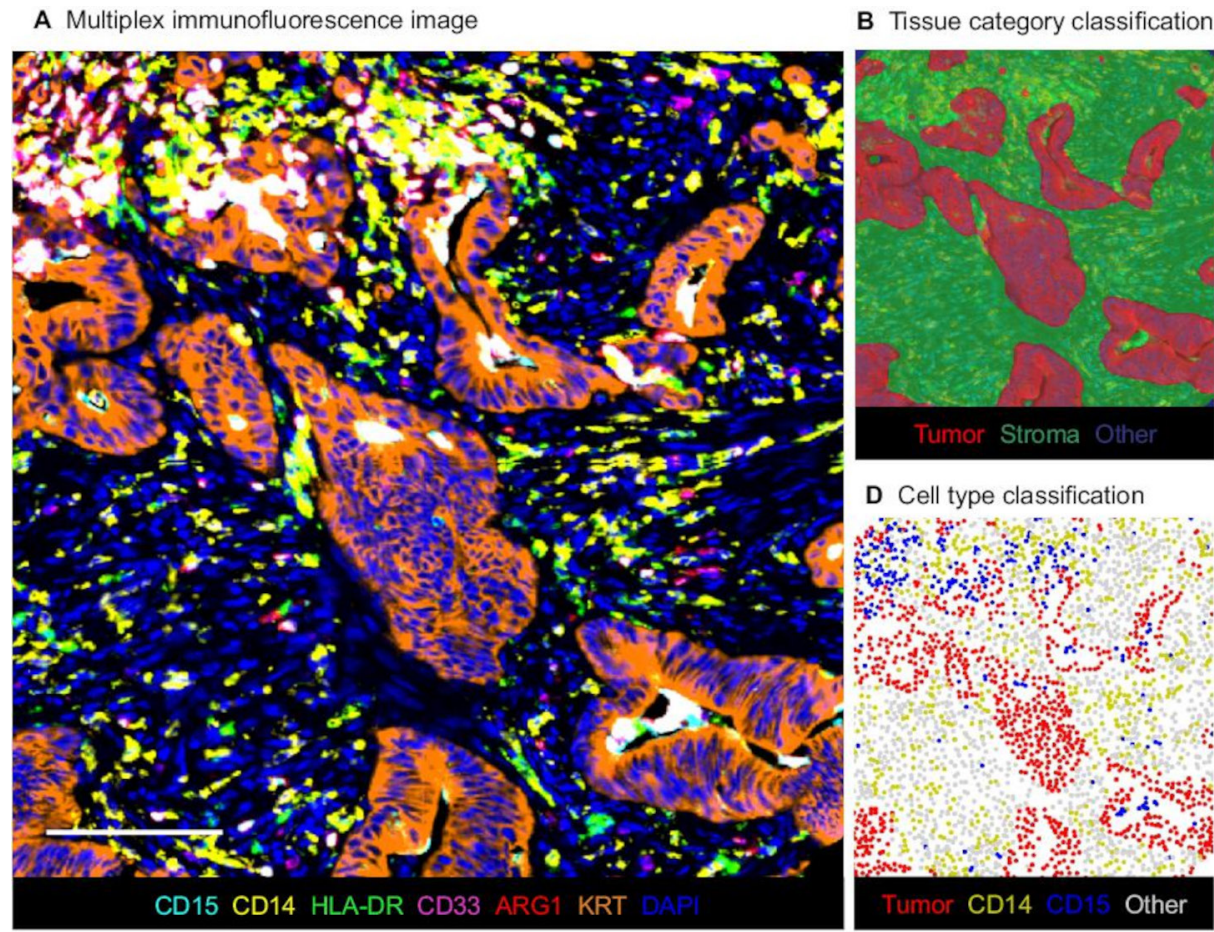

D Cell type classification

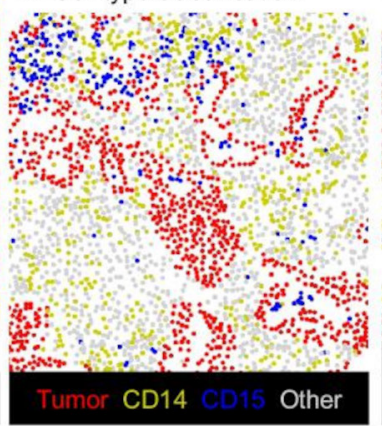

F Myeloid cells

CD14+ cells
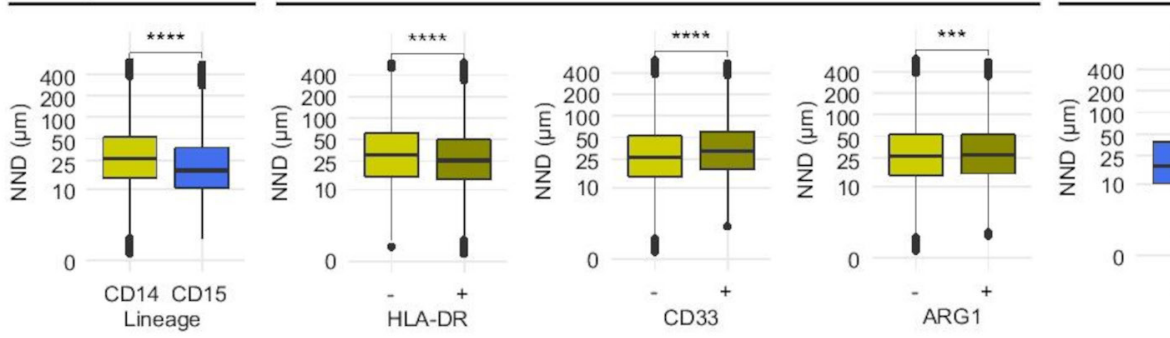

G Myeloid cells
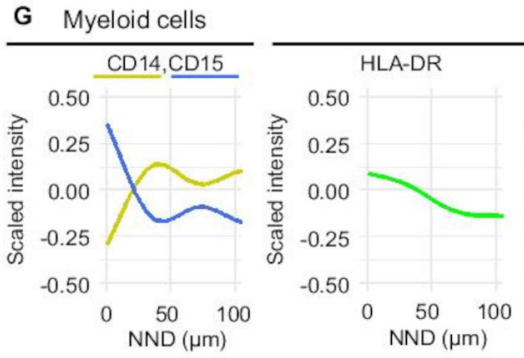

$\mathrm{CD} 14^{+}$cells
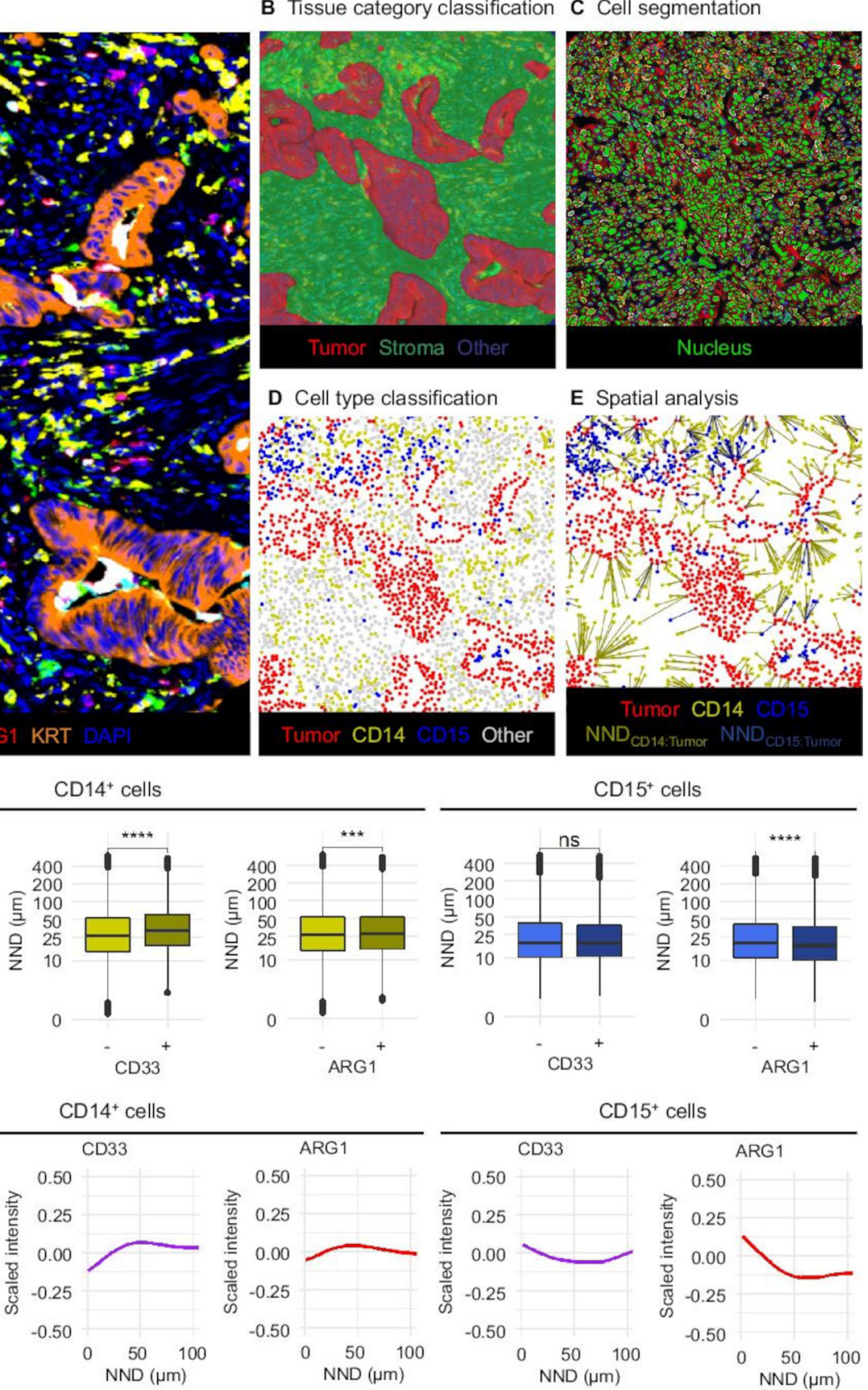

E Spatial analysis

CD15 cells

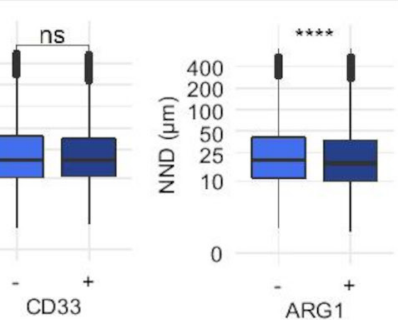

CD15+ cells

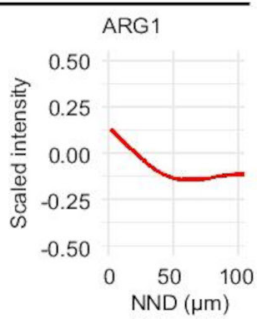

Figure 1 Quantitative, multiplexed analysis of myeloid immune cell populations and their spatial localization. (A) Multiplex immunofluorescence image. Scale bar is $100 \mu \mathrm{m}$. The images were analyzed using supervised machine learning algorithms including tissue category classification (B) cell segmentation (C), and cell type classification (D). (E) Distances from immune cells

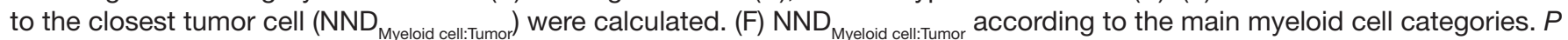
values are for the Wilcoxon rank sum test. (G) Marker signal intensities according to $\mathrm{NND}_{\text {Myeloid cell:Tumor }}{ }^{{ }^{* * \star}} P<0.0001,{ }^{* * \star} P<0.001$, NS: $P>0.005$.

Stained slides were imaged using the Vectra 3.0 multispectral imaging system (Akoya Biosciences, Hopkinton, Massachusetts, USA) equipped with a $20 \times$ objective. ${ }^{29} 30$ TMA core images were reviewed, and images containing more than $10 \%$ tumor across their total area were processed via pathologist-supervised machine learning algorithms using the inForm software package (V.2.4.1; Akoya Biosciences) to classify tissue compartments into three categories (tumor epithelium, stroma and other) and to detect and classify cells into four main categories $\left(\mathrm{CD}_{14}{ }^{+}, \mathrm{CD} 15^{+}\right.$, tumor cell and other) (figure 1A-D) ${ }^{29}{ }^{31}$

Single cell-level data were exported from inForm and further processed with the $\mathrm{R}$ statistical programming language (V.3.5.2; R Foundation for Statistical Computing, Vienna, Austria). Marker intensities were scaled by calculating Z-scores within each TMA, in order to correct for potential staining variability, and myeloid cell subpopulations were defined based on scaled mean intensities of 
HLA-DR (membrane), CD33 (membrane), and ARG1 (cytoplasm) expression in specific cellular compartments of $\mathrm{CD} 14^{+}$monocytic lineage cells and $\mathrm{CD} 15^{+}$granulocytic lineage cells. We conducted spatial point pattern analysis using the spatstat $\mathrm{R}$ package. ${ }^{32}$ For each myeloid cell, we computed the distance to the nearest tumor cells $\left(\mathrm{NND}_{\mathrm{My}-}\right.$ eloid cell:Tumor ) (figure 1E). For visualization, fluorophore intensities of individual cells across all cores (scaled within the cell population-of-interest) as a function of $\mathrm{NND}_{\text {Myeloid }}$ cell:Tumor were plotted with the ggplot2 package using generalized additive model smoothing (formula $=\mathrm{y} \sim \mathrm{s}(\mathrm{x})$ ). We used the G-cross function $\left(G_{\text {Tumor:Mveloid cell }}(r)\right)$ to estimate the probability at least one immune cell being located within a radius $r$ of any tumor cell. For each sample, we calculated the empirical $G_{\text {Tumor:Myeloid cell }}(r)$ distribution functions based on observed nearest neighbor distances, applying edge correction via the Kaplan-Meier method. For survival analysis, we evaluated function values at a radius of $20 \mu \mathrm{m}\left(\mathrm{G}_{\text {Tumor:Myeloid cell }}(20 \mu \mathrm{m})\right)$. This radius was preselected prior to analyses in order to identify immune cell populations likely capable of effective, direct, cellto-cell interaction with tumor cells, consistent with prior reports in multiple tumor types, including colorectal cancer. ${ }^{1933}$

\section{Statistical analysis}

Statistical analyses were performed using SAS software (V.9.4, SAS Institute, Cary, North Carolina, USA). Our primary hypothesis tested the relationship between each myeloid cell density variable and colorectal cancerspecific survival using multivariable-adjusted Cox proportional hazards regression analysis. We used the stringent two-sided $\alpha$ level of 0.005 to judge statistical significance. ${ }^{34}$ All other analyses were secondary, and we interpreted the results cautiously.

We evaluated relationships between myeloid cell densities and clinicopathologic features using the $\chi^{2}$ test and Spearman's rank correlation (rho) test, as appropriate. We used the Kaplan-Meier method to estimate survival functions and the log-rank test to compare survival distributions. To adjust for selection bias due to tissue availability, the IPW method ${ }^{35-37}$ was used with multivariable-adjusted Cox proportional hazards regression models that assessed the HRs for colorectal cancer-specific mortality according to ordinal myeloid cell density categories (Q1-Q4). Further details of the statistical methods used in the survival analyses are shown in online supplemental table S1.

\section{RESULTS}

\section{Characterization of myeloid infiltrates in colorectal cancer}

We evaluated myeloid immune infiltrates in 913 colorectal cancer cases (table 1). Immunofluorescence images were processed with pathologist-supervised machine learning algorithms (figure 1A-D), generating data for 2541019 tumor cells, $663854 \mathrm{CD}_{1} 4^{+}$monocytic cells, and $131470 \mathrm{CD} 15^{+}$granulocytic cells. Fluorophore signal intensity distributions were comparable across the TMAs (online supplemental figure S4). Core-to-core correlation for the densities of both overall $\mathrm{CD} 14^{+}$cells (online supplemental figure S5) and $\mathrm{CD} 15^{+}$cells (online supplemental figure S6) were reasonably high (Spearman rho $=0.50-0.65) . \mathrm{CD} 15^{+}$cell density was moderately correlated with granulocytic cell density as evaluated by digital image analysis of H\&E-stained sections (Spearman rho $=0.44)$.

Overall, CD $14^{+}$monocytic cells (median density 994 cells $/ \mathrm{mm}^{2}$, IQR $609-1580$ cells $/ \mathrm{mm}^{2}$ ) were more common than $\mathrm{CD} 15^{+}$granulocytic cells (median density 97 cells/ $\mathrm{mm}^{2}$, IQR $28-256$ cells $/ \mathrm{mm}^{2}$ ). Densities of both CD $14^{+}$ cells and $\mathrm{CD} 5^{+}$cells were higher in tumor stroma than within tumor intraepithelial regions (median stromal:intraepithelial density ratios 12.5 and 5.0, respectively). The majority $(75 \%)$ of $\mathrm{CD} 14^{+}$monocytic cells expressed the antigen presentation molecule HLA-DR, indicating a mature macrophage phenotype (online supplemental figure S7), although expression intensity was variable. In contrast, expression of myeloid progenitor marker CD33 was relatively rare $(<10 \%)$ in both $\mathrm{CD} 14^{+}$and $\mathrm{CD} 15^{+}$cell lineages (online supplemental figure S7). Expression of immunosuppressive enzyme ARG1 was common in $\mathrm{CD} 15^{+}$cells $(>90 \%)$ yet infrequent in $\mathrm{CD} 14^{+}$cells $(<10 \%)$ (online supplemental figure S7). Intraepithelial and stromal densities of $\mathrm{CD}_{14}{ }^{+}$cells (Spearman rho $=0.55$ ) (or those of $\mathrm{CD} 15^{+}$cells (Spearman rho=0.81)) were positively correlated with each other (online supplemental figure S8), while densities of $\mathrm{CD} 14^{+}$cells and $\mathrm{CD} 15^{+}$cells showed lower correlation (intraepithelial: Spearman rho $=0.33$; stromal: Spearman rho=0.22) (online supplemental figure S8).

We calculated the distance from each myeloid cell to the closest tumor cell (figure 1E). We found that CD15 cells were located, on average, closer to tumor cells than $\mathrm{CD} 14^{+}$cells (figure $1 \mathrm{~F}-\mathrm{G}$ ). Within the $\mathrm{CD} 14^{+}$monocytic population, mature HLA-DR ${ }^{+}$cells were located closer to tumor cells, while immature $\mathrm{CD} 14^{+} \mathrm{CD} 33^{+}$cells were less abundant near tumor cells (figure $1 \mathrm{~F}-\mathrm{G}$ ). Within the $\mathrm{CD}_{15}{ }^{+}$granulocytic population, ARG1 expression was higher in cells located close to tumor cells (figure $1 \mathrm{~F}-\mathrm{G}$ ). Additional example images depicting these myeloid cell spatial distributions are shown in online supplemental figure S9.

\section{Survival analyses}

As our primary hypothesis, we evaluated the prognostic significance of myeloid immune cell densities using a cohort of 4465 incident colorectal carcinoma cases that included the 913 cases with available myeloid cell data and the IPW method to adjust for selection bias due to tissue availability. During the median follow-up time of 16.3 years (IQR 12.8-20.1 years) for censored cases, there were 613 all-cause deaths, including 283 colorectal cancer-specific deaths.

We found that higher stromal densities of $\mathrm{CD} 14^{+}$cells $\left(P_{\text {trend }}<0.0001\right.$; HR for Q4 (vs Q1) of $0.47,95 \%$ CI 0.31 
Table 2 Densities of $\mathrm{CD} 14^{+}$cells and $\mathrm{CD} 15^{+}$cells in tumor intraepithelial, stromal, and overall regions and patient survival with inverse probability weighting (IPW)

\begin{tabular}{|c|c|c|c|c|c|c|c|}
\hline & & Colorec & cancer-specific su & & Overall & rvival & \\
\hline & $\begin{array}{l}\text { No. of } \\
\text { cases }\end{array}$ & $\begin{array}{l}\text { No. of } \\
\text { events }\end{array}$ & $\begin{array}{l}\text { Univariable } \\
\text { HR }(95 \% \mathrm{Cl})^{*}\end{array}$ & $\begin{array}{l}\text { Multivariable } \\
\text { HR }(95 \% \mathrm{Cl})^{*} \dagger\end{array}$ & $\begin{array}{l}\text { No. of } \\
\text { events }\end{array}$ & $\begin{array}{l}\text { Univariable } \\
\text { HR }(95 \% \mathrm{Cl})^{*}\end{array}$ & $\begin{array}{l}\text { Multivariable } \\
\text { HR }(95 \% \mathrm{Cl})^{\star} \dagger\end{array}$ \\
\hline Tumor intra & & & & & & & \\
\hline Q1 & 228 & 88 & 1 (referent) & 1 (referent) & 158 & 1 (referent) & 1 (referent) \\
\hline Q2 & 228 & 64 & 0.67 (0.47 to 0.95$)$ & $0.79(0.56$ to 1.11$)$ & 153 & 0.91 (0.68 to 1.20$)$ & 1.01 (0.76 to 1.33 ) \\
\hline Q4 & 228 & 64 & 0.71 (0.50 to 1.01$)$ & 0.82 (0.55 to 1.22$)$ & 151 & 0.89 (0.66 to 1.18$)$ & 0.91 (0.64 to 1.28 ) \\
\hline$P_{\text {trend }} \neq$ & & & 0.086 & 0.22 & & 0.30 & 0.29 \\
\hline $\mathrm{CD}_{15}{ }^{+} \mathrm{ce}$ & & & & & & & \\
\hline Q1 & 228 & 86 & 1 (referent) & 1 (referent) & 157 & 1 (referent) & 1 (referent) \\
\hline Q2 & 228 & 67 & 0.76 (0.54 to 1.08$)$ & 0.97 (0.69 to 1.35$)$ & 156 & $0.97(0.73$ to 1.30$)$ & 1.09 (0.82 to 1.45$)$ \\
\hline Tumor stron & & & & & & & \\
\hline $\mathrm{CD}_{14}{ }^{+} \mathrm{Ce}$ & & & & & & & \\
\hline Q1 & 228 & 93 & 1 (referent) & 1 (referent) & 169 & 1 (referent) & 1 (referent) \\
\hline Q2 & 228 & 86 & $0.90(0.66$ to 1.24$)$ & 1.07 (0.79 to 1.46$)$ & 158 & 0.96 (0.73 to 1.27$)$ & 1.09 (0.83 to 1.44$)$ \\
\hline Q3 & 229 & 59 & 0.61 (0.42 to 0.86$)$ & 0.68 (0.47 to 0.97$)$ & 145 & 0.73 (0.55 to 0.98$)$ & 0.77 (0.57 to 1.04$)$ \\
\hline Q4 & 228 & 45 & 0.38 (0.26 to 0.56$)$ & 0.47 (0.31 to 0.69$)$ & 141 & 0.55 (0.41 to 0.73$)$ & 0.53 (0.39 to 0.73 ) \\
\hline$P_{\text {trend }} \neq$ & & & $<0.0001$ & $<0.0001$ & & $<0.0001$ & $<0.0001$ \\
\hline $\mathrm{CD} 15^{+} \mathrm{ce}$ & & & & & & & \\
\hline Q1 & 228 & 95 & 1 (referent) & 1 (referent) & 160 & 1 (referent) & 1 (referent) \\
\hline Q2 & 228 & 71 & 0.67 (0.48 to 0.93$)$ & 0.72 (0.53 to 1.00$)$ & 163 & 0.79 (0.60 to 1.05$)$ & 0.77 (0.58 to 1.02$)$ \\
\hline Q2 & 228 & 73 & $0.83(0.59$ to 1.18$)$ & 0.87 (0.62 to 1.24$)$ & 155 & 0.96 (0.72 to 1.28$)$ & 0.99 (0.74 to 1.32$)$ \\
\hline Q3 & 229 & 74 & 0.88 (0.63 to 1.24$)$ & 0.94 (0.66 to 1.33$)$ & 156 & 0.99 (0.75 to 1.33$)$ & 0.95 (0.70 to 1.29 ) \\
\hline Q4 & 228 & 53 & 0.57 (0.39 to 0.83$)$ & 0.68 (0.46 to 1.01$)$ & 141 & 0.74 (0.55 to 1.00$)$ & 0.70 (0.51 to 0.96$)$ \\
\hline$P_{\text {trend }} \neq$ & & & 0.0074 & 0.097 & & 0.075 & 0.034 \\
\hline $\mathrm{CD}_{15}{ }^{+} \mathrm{ce}$ & & & & & & & \\
\hline Q1 & 228 & 88 & 1 (referent) & 1 (referent) & 157 & 1 (referent) & 1 (referent) \\
\hline Q2 & 228 & 73 & 0.78 (0.55 to 1.09$)$ & 0.86 (0.61 to 1.20$)$ & 162 & 0.97 (0.73 to 1.29$)$ & 0.90 (0.68 to 1.19$)$ \\
\hline Q3 & 229 & 67 & 0.59 (0.41 to 0.84$)$ & 0.66 (0.46 to 0.95$)$ & 158 & 0.72 (0.53 to 0.97$)$ & 0.70 (0.51 to 0.95$)$ \\
\hline Q4 & 228 & 55 & 0.63 (0.44 to 0.91$)$ & $0.80(0.54$ to 1.17$)$ & 136 & 0.80 (0.59 to 1.08$)$ & 0.84 (0.61 to 1.15 ) \\
\hline$P_{\text {trend }} \neq$ & & & 0.0048 & 0.092 & & 0.043 & 0.099 \\
\hline
\end{tabular}

*IPW was applied to reduce bias due to the availability of tumor tissue after cancer diagnosis (see 'Statistical analysis' subsection for details).

†The multivariable Cox regression model initially included sex, age, year of diagnosis, family history of colorectal cancer, tumor location, tumor differentiation, disease stage, microsatellite instability, $\mathrm{CpG}$ island methylator phenotype, KRAS, BRAF, and PIK3CA mutations, and long-interspersed nucleotide element-1 methylation level. A backward elimination with a threshold $P$ of 0.05 was used to select variables for the final models.

$\ddagger$ The $P_{\text {trend }}$ value was calculated across the ordinal quartiles of each myeloid cell density within tumor epithelial, stromal, and overall regions in the IPW-adjusted Cox regression model.

to 0.69 ) and $\mathrm{CD} 15^{+}$cells $\left(P_{\text {trend }}=0.0036\right.$; HR for Q4 (vs $\mathrm{Q} 1)$ of $0.61,95 \% \mathrm{CI} 0.42$ to 0.89 ) were associated with longer cancer-specific survival independent of potential confounding factors such as disease stage and MSI status (table 2, figure 2 and online supplemental figure S10).
In contrast, intraepithelial $\mathrm{CD} 14^{+}$or $\mathrm{CD}_{1} 5^{+}$cell densities were not statistically significant $\left(P_{\text {trend }}>0.01\right.$ in multivariable models at the $\alpha$ level of 0.005 ), highlighting the value of studying immune cell densities in defined tissue regions. 
A

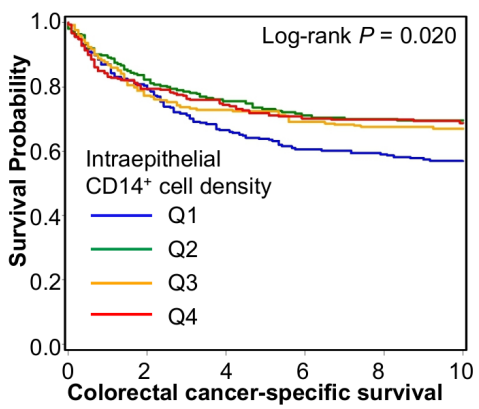

(Years)

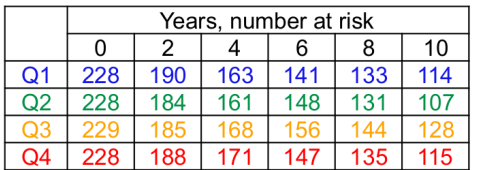

D

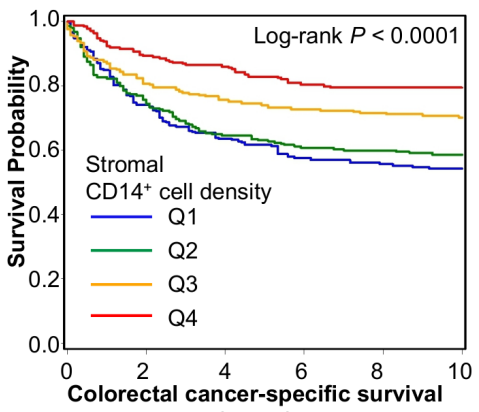

(Years)
B

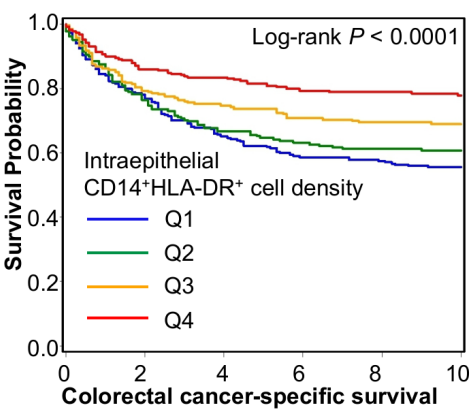

(Years)

\begin{tabular}{|c|c|c|c|c|c|c|}
\hline & \multicolumn{7}{|c|}{ Years, number at risk } \\
\cline { 2 - 7 } & 0 & 2 & 4 & 6 & 8 & 10 \\
\hline Q1 & 228 & 184 & 158 & 137 & 130 & 111 \\
\hline Q2 & 228 & 174 & 148 & 133 & 115 & 96 \\
\hline Q3 & 229 & 188 & 170 & 159 & 146 & 125 \\
\hline Q4 & 228 & 201 & 187 & 163 & 152 & 132 \\
\hline
\end{tabular}

E

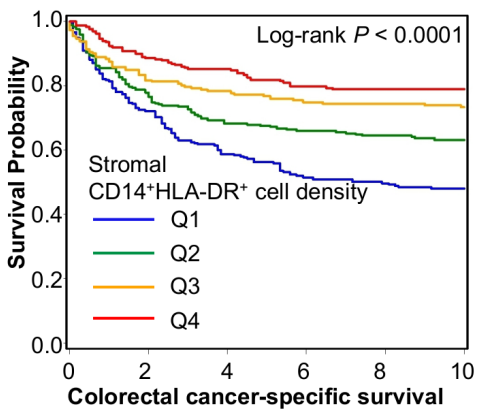

(Years)
C

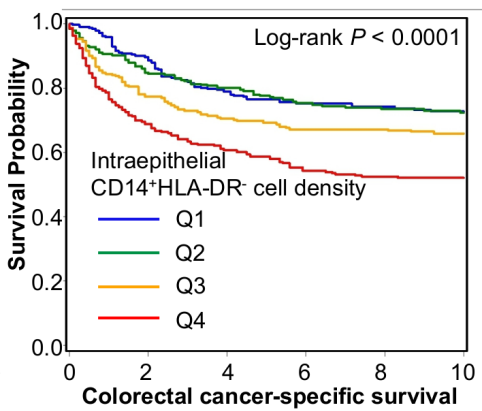

(Years)

\begin{tabular}{|c|c|c|c|c|c|c|}
\hline & \multicolumn{7}{|c|}{ Years, number at risk } \\
\cline { 2 - 7 } & 0 & 2 & 4 & 6 & 8 & 10 \\
\hline Q1 & 228 & 207 & 182 & 163 & 152 & 136 \\
\hline Q2 & 228 & 190 & 175 & 158 & 143 & 119 \\
\hline Q3 & 229 & 187 & 164 & 152 & 143 & 117 \\
\hline Q4 & 228 & 163 & 142 & 119 & 105 & 92 \\
\hline
\end{tabular}

$F$

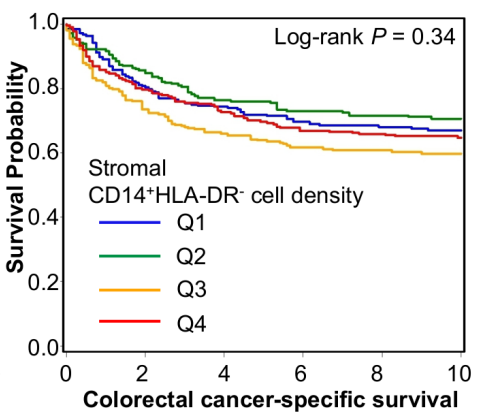

(Years)

\begin{tabular}{|c|c|c|c|c|c|c|}
\hline & \multicolumn{7}{|c|}{ Years, number at risk } \\
\cline { 2 - 7 } & 0 & 2 & 4 & 6 & 8 & 10 \\
\hline Q1 & 228 & 175 & 150 & 130 & 119 & 101 \\
\hline Q2 & 228 & 177 & 153 & 137 & 124 & 100 \\
\hline Q3 & 229 & 186 & 168 & 156 & 144 & 127 \\
\hline Q4 & 228 & 209 & 192 & 169 & 156 & 136 \\
\hline
\end{tabular}

\begin{tabular}{|c|c|c|c|c|c|c|}
\hline & \multicolumn{6}{|c|}{ Years, number at risk } \\
\cline { 2 - 7 } & 0 & 2 & 4 & 6 & 8 & 10 \\
\hline Q1 & 228 & 168 & 139 & 116 & 105 & 90 \\
\hline Q2 & 228 & 183 & 162 & 149 & 136 & 108 \\
\hline Q3 & 229 & 188 & 174 & 161 & 149 & 131 \\
\hline Q4 & 228 & 208 & 188 & 166 & 153 & 135 \\
\hline
\end{tabular}

\begin{tabular}{|c|c|c|c|c|c|c|}
\hline \multirow{2}{*}{} & \multicolumn{7}{|c|}{ Years, number at risk } \\
\cline { 2 - 7 } & 0 & 2 & 4 & 6 & 8 & 10 \\
\hline Q1 & 228 & 193 & 174 & 158 & 141 & 126 \\
\hline Q2 & 228 & 193 & 172 & 154 & 145 & 125 \\
\hline Q3 & 229 & 177 & 153 & 136 & 126 & 102 \\
\hline Q4 & 228 & 184 & 164 & 144 & 131 & 111 \\
\hline
\end{tabular}

Figure 2 Inverse probability weighting-adjusted Kaplan-Meier survival curves for colorectal cancer-specific survival according to ordinal quartile categories (Q1-Q4) of intraepithelial (A-C) and stromal (D-F) densities of CD14 ${ }^{+}$cells classified by HLA-DR expression.

Having identified an association between $\mathrm{CD} 14^{+}$monocytic cell density and longer survival, we sought to further classify these cells according to maturity using HLA-DR expression. This revealed a significant association between prognosis and degree of maturity (table 3, figure 2). Higher densities of both intraepithelial $\left(P_{\text {trend }}=0.0002 ; \mathrm{HR}\right.$ for Q4 (vs Q1) of $0.48,95 \%$ CI 0.31 to 0.76 ) and stromal $\left(P_{\text {trend }}<0.0001\right.$; HR for Q4 (vs Q1) of $0.42,95 \%$ CI 0.29 to $0.63) \mathrm{CD} 14^{+} \mathrm{HLA}-\mathrm{DR}^{+}$mature monocytic cells were associated with lower cancer-specific mortality while, conversely, higher intraepithelial densities of CD14 ${ }^{+} \mathrm{HLA}^{-} \mathrm{DR}^{-}$immature monocytic cells were associated with higher cancerspecific mortality $\left(P_{\text {trend }}=0.0003\right.$; HR for Q4 (vs Q1) of $1.78,95 \%$ CI 1.25 to 2.55 ). Given that MSI status strongly influences the antitumor immune response ${ }^{38}$ we further examined whether the prognostic association of $\mathrm{CD} 14^{+} \mathrm{H}-$ $\mathrm{LA}^{-D R^{+}}$or CD14 ${ }^{+} \mathrm{HLA}^{-\mathrm{DR}^{-}}$myeloid cell densities might differ by MSI status and found that the difference was not statistically significant at an $\alpha$ level of $0.005\left(P_{\text {interaction }}\right.$ $>0.03$ ) (online supplemental table S3).
Densities of immature $\mathrm{CD} 14^{+}$cells or $\mathrm{CD} 15^{+}$cells expressing CD33 were not significantly associated with cancer-specific survival, irrespective of stromal or intraepithelial location. In contrast, the prognostic associations of $\mathrm{CD} 14^{+} \mathrm{CD} 33^{-}$cell or $\mathrm{CD} 15^{+} \mathrm{CD} 33^{-}$cell densities were comparable to those of overall $\mathrm{CD} 14^{+}$or $\mathrm{CD} 15^{+}$cell densities, respectively, as most $\mathrm{CD} 14^{+}$cells and $\mathrm{CD} 15^{+}$cells were CD33- (online supplemental table S4). CD $14^{+}$or $\mathrm{CD} 15^{+}$ cells expressing immunosuppressive marker ARG1 were not significantly associated with mortality (online supplemental table S5).

\section{Relationships with tumor and patient characteristics}

In order to understand the factors that govern myeloid cell infiltration in CRC, we analyzed the relationships between myeloid cell densities and clinicopathologic features (online supplemental table S11). Higher densities of both intraepithelial CD14 ${ }^{+}$cells (including HLA$\mathrm{DR}^{+}$and HLA-DR ${ }^{-}$subpopulations) and $\mathrm{CD} 15^{+}$cells were associated with MSI high status and poor differentiation 
Table 3 Densities of CD14 ${ }^{+}$cells classified according to HLA-DR expression in tumor intraepithelial and stromal regions and patient survival with inverse probability weighting (IPW)

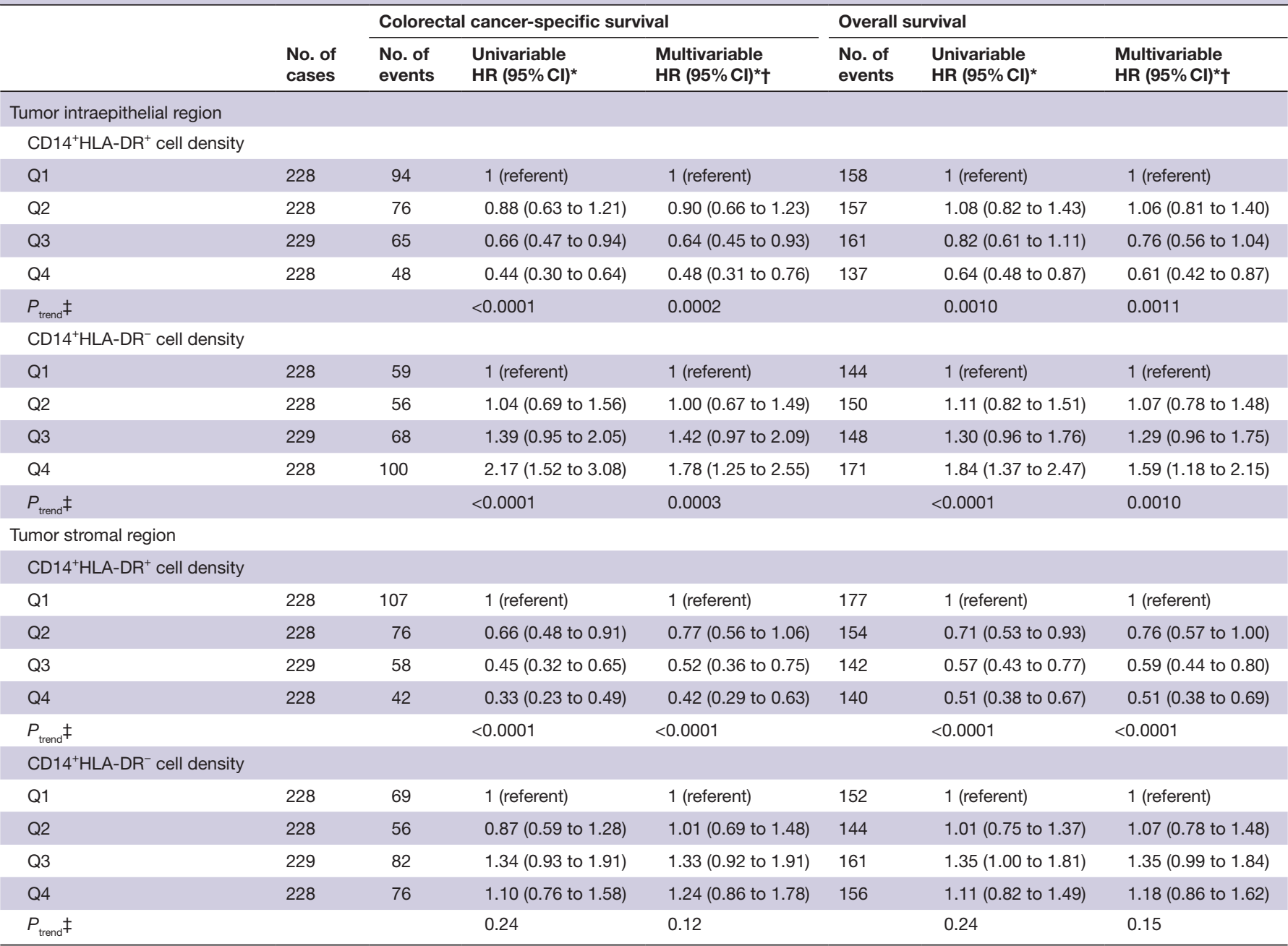

*IPW was applied to reduce bias due to the availability of tumor tissue after cancer diagnosis (see 'Statistical analysis' subsection for details).

†The multivariable Cox regression model initially included sex, age, year of diagnosis, family history of colorectal cancer, tumor location, tumor differentiation, disease stage, microsatellite instability, $\mathrm{CpG}$ island methylator phenotype, KRAS, BRAF, and PIK3CA mutations, and long-interspersed nucleotide element-1 methylation level. A backward elimination with a threshold $P$ of 0.05 was used to select variables for the final models.

$\ddagger$ The $P_{\text {trend }}$ value was calculated across the ordinal quartiles of each myeloid cell density within tumor epithelial and stromal regions in the IPW-adjusted Cox regression model.

$(p<0.0002)$. Higher intraepithelial $\mathrm{CD} 14^{+}$and $\mathrm{CD} 14^{+} \mathrm{H}^{-}$ LA-DR ${ }^{+}$cell densities were also associated with higher neoantigen load $(p<0.0002)$. In stroma, higher densities of $\mathrm{CD} 14^{+}$and $\mathrm{CD} 14^{+} \mathrm{HLA}^{-\mathrm{DR}^{+}}$cells were associated with lower stage $(p<0.0001)$. Additionally, higher stromal densities of $\mathrm{CD} 14^{+}$cells, CD $14^{+} \mathrm{HLA}^{-D R^{+}}$cells and $\mathrm{CD} 15^{+}$ cells $(\mathrm{p}<0.003)$ were associated with MSI-high status.

Considering the opposing survival associations for $\mathrm{CD}_{14}{ }^{+} \mathrm{HLA}^{-D R^{+}}$and CD14 ${ }^{+} \mathrm{HLA}^{-D R^{-}}$cells, we assessed whether these populations might also be differentially associated with lymphocytic reaction patterns (online supplemental figure S12). We found that higher intraepithelial and stromal densities of $\mathrm{CD} 14^{+} \mathrm{HLA}-\mathrm{DR}^{+}$cells were associated with more intense lymphocytic reaction patterns (tumor-infiltrating lymphocytes, intratumoral periglandular reaction, peritumoral reaction, and Crohn's-like lymphoid reaction) (all $\mathrm{p}<0.0001$ ), while $\mathrm{CD} 14^{+} \mathrm{HLA}^{-D R^{-}}$cell density was not significantly associated with any lymphocytic reaction pattern $(\mathrm{p}>0.02$ with $\alpha=0.005$ ) (online supplemental figure S12).

\section{Spatial analyses with G-cross function}

Given our ability to precisely define the positions of individual tumor cells and myeloid cells, we sought to evaluate the prognostic significance of proximity between tumor cells and myeloid cells. We used the $\mathrm{G}_{\text {Tumor:Myeloid cell }}(\mathrm{r})$ function to evaluate the likelihood of any tumor cell in the sample having at least one myeloid cell (of the specified type) within a specified radius $r$. Higher function values at a given radius $r$ indicate greater colocalization of the specified myeloid cell type with tumor cells (examples in figure $3 \mathrm{~A}-\mathrm{B}$, online supplemental figure S13A-B).

We found that the values of functions evaluating overall $\mathrm{CD}_{14} 4^{+}$and $\mathrm{CD} 15^{+}$populations within a $20 \mu \mathrm{m}$ radius of tumor cells $\left(\mathrm{G}_{\text {Tumor:CD14+ }}(20 \mu \mathrm{m})\right.$ and $\left.\mathrm{G}_{\text {Tumor:CD15+ }}(20 \mu \mathrm{m})\right)$ were not significantly associated with cancer-specific 


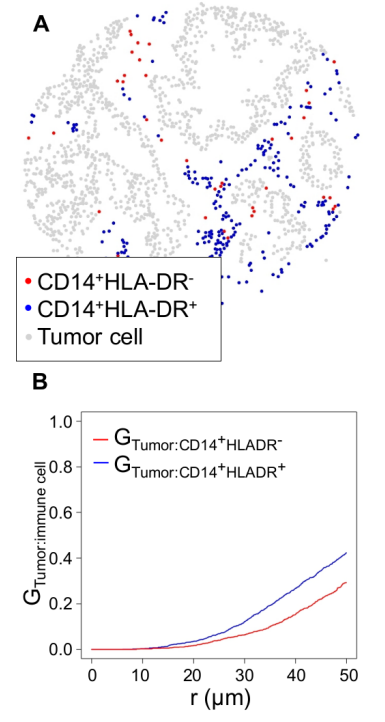

C

$\mathrm{G}_{\text {Tumor:CD14 }}{ }^{+}$LLADR $^{+}(20 \mu \mathrm{m})$

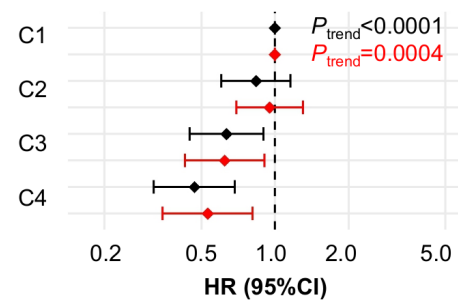

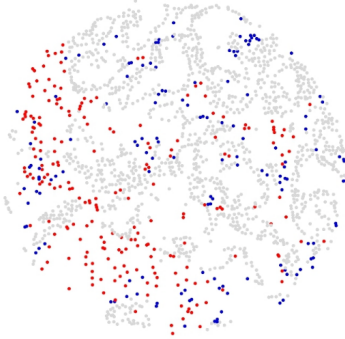
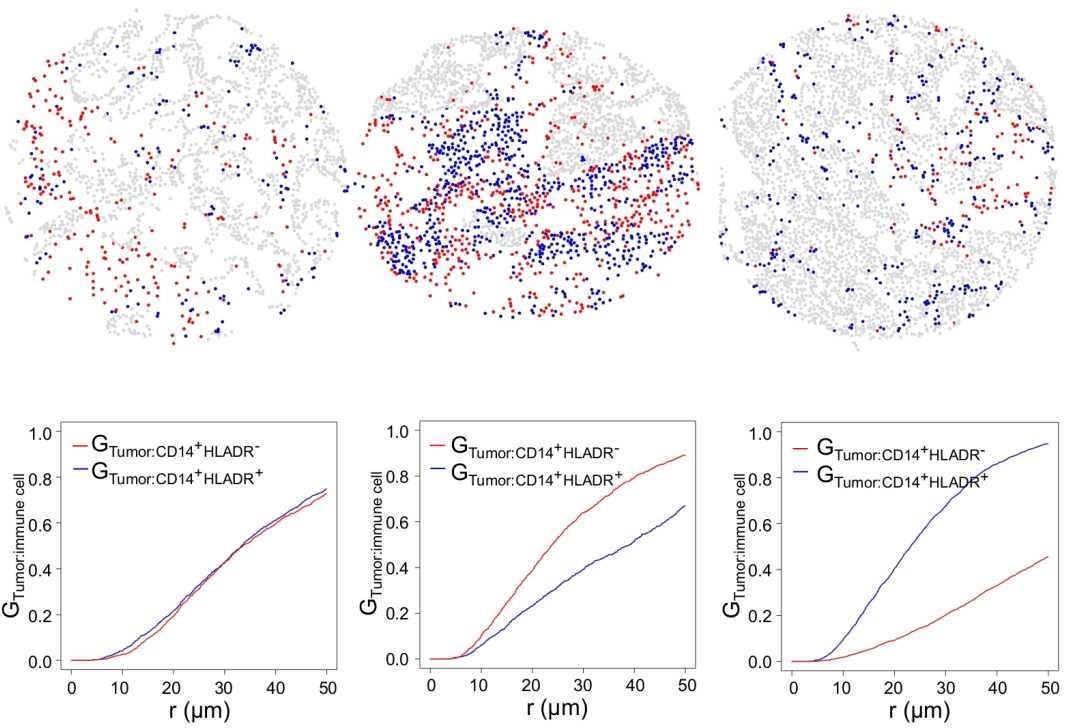

$\mathrm{G}_{\text {Tumor:CD14 }}{ }^{+} \mathrm{HLADR}^{+}(20 \mu \mathrm{m})-$

$\mathrm{G}_{\text {Tumor:CD14 } 4^{+} \text {HLADR }}(20 \mu \mathrm{m})$
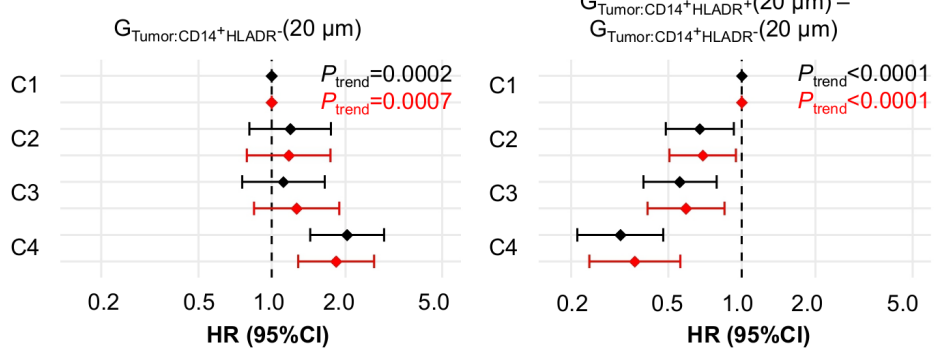

Figure 3 Spatial analysis of $C D 14^{+} H L A-D R^{+}$and $C D 14^{+} H L A-D R^{-}$myeloid immune infiltrates with the tumor:myeloid cell Gcross function $\left(G_{\text {Tumor:Myeloid cell }}\right)$. ( $(A$ and $B)$ Example myeloid cell patterns and corresponding $G_{\text {Tumor:Myeloid cell }}(r)$ plots, estimating the probability of any tumor cell having at least one neighboring myeloid cell of the specified type within an $r \mu \mathrm{m}$ radius. (C) Univariable (black) and multivariable (red) Cox proportional hazards regression models for cancer-specific survival according to $\mathrm{G}_{\text {Tumor:Myeloid cell }}(20 \mu \mathrm{m})$ ordinal quartile categories $(\mathrm{C} 1-\mathrm{C} 4)$. The multivariable Cox regression models initially included sex, age, year of diagnosis, family history of colorectal cancer, tumor location, tumor differentiation, disease stage, microsatellite instability, $\mathrm{CpG}$ island methylator phenotype, KRAS, BRAF, and PIK3CA mutations, and long-interspersed nucleotide element-1 methylation level. A backward elimination with a threshold $P$ of 0.05 was used to select variables for the final models.

survival $\left(P_{\text {trend }}>0.1\right)$ (online supplemental figure S13). Conversely, the values of functions evaluating both mature $\mathrm{CD} 14^{+} \mathrm{HLA}^{-D R^{+}}\left(P_{\text {trend }}=0.0004\right)$ and immature CD14 ${ }^{+}$HLA-DR $^{-}$subsets $\left(P_{\text {trend }}=0.0007\right)$ were significantly prognostic and showed opposite effects (figure 3 ). Accordingly, their difference $\left(\mathrm{G}_{\text {Tumor:CD14+HLADR }}(20 \mu \mathrm{m})\right.$ $\left.\mathrm{G}_{\text {Tumor:CD14+HLADR- }}(20 \mu \mathrm{m})\right)$, where high values represent a high likelihood of any tumor cell being colocated with at least one mature monocytic cell yet a low likelihood of colocation with an immature monocytic cell, exhibited an even stronger prognostic association $\left(P_{\text {trend }}<0.0001\right.$; HR for Q4 (vs Q1), 0.37, 95\% CI 0.24 to 0.57). Given that this association could be confounded by cell density, we directly compared the prognostic power of mature and immature monocytic cell densities and the G-cross proximity measurement by including the proximity and density variables in one Cox regression model, with reciprocal adjustment (online supplemental table S6). This analysis indicated that both CD14 ${ }^{+} \mathrm{HLA}_{-} \mathrm{DR}^{+}$and CD14 $4^{+}$HLA-DR ${ }^{-}$cell densities and the G-cross proximity measurement independently contributed to prognostic significance.

\section{DISCUSSION}

We leveraged recent technical advances in multiplexed immunofluorescence ${ }^{8}$ to build a novel assay enabling in situ characterization of detailed myeloid cell phenotypes in colorectal cancer. In addition to monocytic (CD14) and granulocytic (CD15) lineage markers, our panel contained macrophage maturation marker HLA-DR (an MHC class II cell surface receptor that supports antigen presentation to T cells), ${ }^{39}$ myeloid marker CD33 (a transmembrane sialic acid binding receptor downregulated during myeloid cell maturation), ${ }^{40}$ immunosuppressive marker ARG1 (an enzyme catalyzing the hydrolysis of arginine to ornithine and urea), ${ }^{10}$ and pan-cytokeratin (KRT) as a tumor cell marker. This panel design enabled us to simultaneously examine myeloid cell lineage (monocytic vs granulocytic), maturity (HLA-DR and CD33), and suppressive potential (ARG1) in a manner not possible with single marker approaches. This combinatorial approach was required for accurate cell identification since most of the included markers are not specific for the myeloid cell populations under study. For example, HLA-DR can be expressed by B cells and dendritic cells 
in addition to monocytic lineage cells, ${ }^{39} 41$ while CD33 is expressed by mast cells. ${ }^{22}$

We applied our assay to 913 colorectal cancers in two US nationwide prospective cohort studies. We found that high $\mathrm{CD} 14^{+}$monocytic and $\mathrm{CD} 15^{+}$granulocytic cell densities in tumor stroma were associated with low cancerspecific mortality independent of potential confounding factors such as disease stage, MSI status, and $B R A F, K R A S$, and PIK3CA mutation status. Furthermore, we found that these populations were heterogenous, and finer-grained classification of $\mathrm{CD}_{1} 4^{+}$monocytic cells according to HLA-DR expression revealed opposing prognostic roles for mature HLA-DR ${ }^{+}$and immature HLA-DR ${ }^{-}$subsets within intraepithelial regions, with high density of mature HLA-DR $^{+}$cells associating with lower cancer-specific mortality and high density of intraepithelial immature HLA-DR $^{-}$cells associating with higher cancer-specific mortality.

Since the discovery of the expansion of immature myeloid cells in cancer, ${ }^{45}$ a multitude of studies have assessed the potential mechanisms involved in their tumorpromoting activity. ${ }^{6}{ }^{42}$ Experimental evidence suggests that these cells can produce anti-inflammatory cytokines, including interleukin $10^{43}$ and transforming growth factor beta $1,{ }^{44}$ thereby reducing $\mathrm{T}$ cell infiltration. ${ }^{45}$ Moreover, they may produce angiogenic mediators or growth factors promoting tumor cell proliferation. ${ }^{45}{ }^{46}$ Conversely, the mechanism linking mature HLA-DR ${ }^{+}$monocytic cells with better survival may be related to this cell type's ability to efficiently present antigens to T lymphocytes, ${ }^{47}$ thereby activating antitumor immunity. Indeed, we found that high densities of CD14 ${ }^{+} \mathrm{HLA}_{-} \mathrm{DR}^{+}$cells, but not $\mathrm{CD} 14^{+} \mathrm{H}^{-}$ LA-DR ${ }^{-}$cells, were associated with high lymphocytic reaction scores.

In addition to $\mathrm{CD} 14^{+}$monocytic cells, higher $\mathrm{CD} 15^{+}$ granulocytic cell density in tumor stromal regions was associated with favorable prognosis. This is consistent with several previous studies that have evaluated the prognostic significance of CEACAM8 ${ }^{+}\left(\mathrm{CD} 66 \mathrm{~b}^{+}\right)^{2648} 49$ granulocytic cells in colorectal cancer and stands in contrast to other tumor types, such as hepatocellular carcinoma ${ }^{50}$ and renal cell carcinoma, ${ }^{51}$ where strong granulocytic infiltrates have been associated with worse prognosis. These tumor type-specific results may be attributable to the diversity and plasticity of granulocytes within the tumor microenvironment, as such cells can participate in both tumorpromoting functions (such as angiogenesis, extracellular matrix remodeling, and immunosuppression) and antitumor roles (such as direct killing of tumor cells). ${ }^{45}$ Our finding of the favorable prognostic value of $\mathrm{CD}_{15} 5^{+}$granulocytes suggests that the antitumorigenic granulocytic subpopulations may outnumber protumorigenic ones within the colorectal cancer microenvironment.

ARG1 is considered one of the most important immunoregulatory enzymes in the tumor microenvironment, contributing to suppression of the $\mathrm{T}$ cell response through arginine depletion. ${ }^{1052}$ In murine tumor models, high ARG1 expression has commonly been observed in monocytic lineage cells whereas, in humans, strong expression is most frequently seen on polymorphonuclear cells instead of monocytic cells. ${ }^{10}{ }^{53}$ Consistent with these prior human studies, we found that ARG1 positivity was common in $\mathrm{CD}_{15} 5^{+}$granulocytic cells but relatively rare in $\mathrm{CD}_{1} 4^{+}$monocytic cells in the colorectal cancer microenvironment in a large human population-based sample. Contrary to our exploratory hypothesis, higher densities of granulocytic or monocytic $\mathrm{ARG}^{+}{ }^{+}$cells were not associated with adverse clinical outcome. This may be related to: (1) a lower functional relevance for ARG1 as compared with other immunosuppressive pathways in colorectal cancer (such as the IDO1 pathway and the PDCD1 (PD-1)-CD274 (PD-L1) pathway, ${ }^{52} 54$ which were not evaluated in this study), (2) potential production of proinflammatory mediators by $\mathrm{ARG}^{+}$cells, thereby activating the immune response, or (3) additional unidentified factors, all of which are relevant topics for future studies. Of note, murine and human immune systems may have significant differences ${ }^{55}$; many promising findings in mouse models have not translated into the treatment of human disease, supporting the clinical relevance of large-scale analyses of the tumor microenvironment using human specimens.

We discovered previously unappreciated differences in the infiltration patterns of various myeloid subsets. Both $\mathrm{CD} 14^{+}$monocytic cells and $\mathrm{CD} 15^{+}$granulocytic cells were preferably located in tumor stroma, although $\mathrm{CD} 15^{+}$cells were, on average, closer to tumor cells than $\mathrm{CD} 14^{+}$cells. Within the $\mathrm{CD} 14^{+}$population, mature CD14 ${ }^{+} \mathrm{HLA}-\mathrm{DR}^{+}$ cells (and CD $14^{+} \mathrm{CD} 33^{-}$cells) were located closer to tumor cells as compared with immature CD14 ${ }^{+} \mathrm{HLA}_{-} \mathrm{DR}^{-}$cells (and $\mathrm{CD} 14^{+} \mathrm{CD} 33^{+}$cells). This suggests that the maturity of $\mathrm{CD} 14^{+}$cells may influence their interaction with tumor cells, with the HLA-DR ${ }^{+}$subset having closer contact with tumor cells as compared with the HLA-DR ${ }^{-}$subset. Alternatively, close contact with tumor cells may itself drive the maturation of $\mathrm{CD} 14^{+}$cells. We hypothesize that these mature monocytic cells may participate in tumor cell phagocytosis, considering their association with favorable prognosis. Notably, however, CD14 ${ }^{+} \mathrm{HLA}_{-} \mathrm{DR}^{+}$cells were associated with longer survival in both intraepithelial and stromal compartments, while the adverse prognostic effect of CD14 ${ }^{+} \mathrm{HLA}^{-D R^{-}}$cells was only seen in the intraepithelial compartment, suggesting that the significance of the immature HLA-DR ${ }^{-}$subset rather than the mature HLA-DR ${ }^{+}$subset may be dependent on the close interaction with tumor cells. Modeling the proximity of tumor cells with CD14 $4^{+}$HLA-DR ${ }^{+}$and CD14 ${ }^{+}$HLA-DR $^{-}$cells with G-cross function, we found that the G-cross proximity measurement (evaluating the difference in the likelihood of any tumor cell in the sample having at least one $\mathrm{CD}_{14}{ }^{+} \mathrm{HLA}-\mathrm{DR}^{+}$cell vs CD $14^{+} \mathrm{HLA}^{-\mathrm{DR}^{-}}$cell within $20 \mu \mathrm{m}$ radius) was a prognostic factor independent of the densities of these cells, suggesting that proximity measurement of specific myeloid populations may improve the prognostic categorization compared with simpler, densitybased analyses. 
Each colorectal cancer is unique and arises through the complex interplay between endogenous and exogenous factors, neoplastic cells, and non-neoplastic cells. ${ }^{56}$ The current clinical practice recommendations for colorectal cancer are mainly based on disease stage,$^{57}$ although there is an increasing need for more accurate prognostic and predictive parameters to guide personalized treatment. While our results support the prognostic significance of myeloid cells in colorectal cancer, further investigation is required to validate the findings and compare our assay to other methods for evaluating immune cell infiltrates, such as the $\mathrm{T}$ cell based Immunoscore that has been internationally validated using samples from more than 2600 patients. $^{58}$

There are important limitations that need to be considered in the interpretation of these results. First, the study was based on TMAs. Myeloid immune infiltrates in a small tissue sample may not fully reflect overall tumor infiltration. However, multiple tumor cores were examined for most tumors (median 2), and we observed reasonably high core-to-core correlation, supporting the validity of the TMA approach. Second, while our multiplex immunofluorescence assay could detect more detailed myeloid cell phenotypes than standard immunohistochemistry, the number of markers was still limited. The best characterized human MDSC subsets include monocytic CD14 ${ }^{+}$HLA-DR CD $15^{-}$cells and polymorphonuclear $\mathrm{CD} 15^{+} \mathrm{CD} 14^{-}$cells within the myeloid population, while less mature MDSCs are characteristically HLA-DR-CD $33^{+} .{ }^{6}$ However, these phenotypic criteria do not enable unequivocal distinction of monocytic MDSCs from macrophages and monocytes, or polymorphonuclear MDSCs from mature neutrophils or eosinophils; functional suppression assays would be required to confirm the suppressive activity of the cells ${ }^{6}$ and are not compatible with archival FFPE material. Experimental studies evaluating the functional and biologic roles of various MDSC markers are also warranted, and orthogonal methods could be contrasted to protein expression based methods for MDSC-like cell detection. Third, data on cancer treatments were limited. Nonetheless, treatment decisions were likely based predominantly on disease stage, which was included in the multivariable Cox regression models. Future studies should investigate potential interactions between treatment and myeloid or monocytic cells in tumor tissues in relation to clinical outcomes.

The strengths of the study include the use of multiplex immunofluorescence combined with digital image analysis to phenotype granulocytic and monocytic myeloid cells in the tumor microenvironment. Our comprehensive tumor dataset enabled us to control for a large number of potential confounders, such as MSI status, CIMP status, KRAS, BRAF, and PIK3CA mutation status, and LINE-1 methylation. The study population was derived from cases in many hospitals across the USA, increasing the generalizability of the results compared with retrospective, single institution studies. We were able to control for selection bias due to tissue availability using the IPW method, as we could ascertain nearly all incident colorectal cancer cases in the cohort. Moreover, we used a stringent $\alpha$ level of 0.005 to reduce the possibility of false positive findings, thereby improving the likelihood that our findings are reproduced. ${ }^{34}$ However, additional validation in independent datasets will still be required to confirm the results.

In conclusion, myeloid cells exhibit strong, subsetspecific prognostic significance in colorectal cancer, with mature $\mathrm{CD}_{14}{ }^{+} \mathrm{HLA}_{-} \mathrm{DR}{ }^{+}$and immature $\mathrm{CD} 14^{+} \mathrm{HLA}^{-D R^{-}}$ monocytic phenotypes most notably showing opposite effects (favorable and unfavorable, respectively). These results support multimarker evaluation of myeloid immune infiltrates as a robust, quantitative prognostic tool in colorectal cancer.

\section{Author affiliations}

${ }^{1}$ Cancer and Translational Medicine Research Unit, Medical Research Center Oulu, Oulu University Hospital, and University of Oulu, Oulu, Finland

${ }^{2}$ Department of Medical Oncology, Dana-Farber Cancer Institute and Harvard Medical School, Boston, Massachusetts, USA

${ }^{3}$ Program in MPE Molecular Pathological Epidemiology, Department of Pathology, Brigham and Women's Hospital and Harvard Medical School, Boston, Massachusetts, USA

${ }^{4}$ Department of Surgery, Jikei University School of Medicine, Tokyo, Japan

${ }^{5}$ Conjoint Gastroenterology Department, QIMR Berghofer Medical Research Institute, Herston, Queensland, Australia

${ }^{6}$ Department of Epidemiology, Harvard University T.H. Chan School of Public Health, Boston, Massachusetts, USA

${ }^{7}$ Department of Nutrition, Harvard University T.H. Chan School of Public Health, Boston, Massachusetts, USA

${ }^{8}$ Clinical and Translational Epidemiology Unit, Massachusetts General Hospital and Harvard Medical School, Boston, Massachusetts, USA

${ }^{9}$ Division of Gastroenterology, Massachusetts General Hospital, Boston, Massachusetts, USA

${ }^{10}$ Channing Division of Network Medicine, Department of Medicine, Brigham and Women's Hospital and Harvard Medical School, Boston, Massachusetts, USA

${ }^{11}$ Department of Immunology and Infectious Diseases, Harvard University T.H. Chan School of Public Health, Boston, Massachusetts, USA

${ }^{12}$ Department of Biostatistics, Harvard University T.H. Chan School of Public Health, Boston, Massachusetts, USA

${ }^{13}$ Yale University Yale Cancer Center, New Haven, Connecticut, USA

${ }^{14}$ Department of Medicine, Yale School of Medicine, New Haven, Connecticut, USA

${ }^{15}$ Smilow Cancer Hospital, New Haven, Connecticut, USA

${ }^{16}$ Broad Institute of MIT and Harvard, Cambridge, Massachusetts, USA

${ }^{17}$ Department of Medicine, Brigham and Women's Hospital and Harvard Medical School, Boston, Massachusetts, USA

${ }^{18}$ Cancer Immunology and Cancer Epidemiology Programs, Dana-Farber Harvard Cancer Center, Boston, Massachusetts, USA

Acknowledgements We would like to thank the participants and staff of the Nurses' Health Study and the Health Professionals Follow-up Study for their valuable contributions as well as the following state cancer registries for their help: AL, AZ, AR, CA, CO, CT, DE, FL, GA, ID, IL, IN, IA, KY, LA, ME, MD, MA, MI, NE, NH, NJ, NY, NC, ND, OH, OK, OR, PA, RI, SC, TN, TX, VA, WA and WY. The authors assume full responsibility for analyses and interpretation of these data.

Contributors JPV, SAV, MG, S0, and JAN: developed the main concept and designed the study. ATC, CSF, MG and SO: wrote grant applications. JPV, KH, SAV, MCL, JB, ATC, RN, CSF, JAM, SO, and JAN were responsible for collection of tumor tissue, and acquisition of epidemiologic, clinical and tumor tissue data, including histopathological, immunohistochemical, and immunofluorescent characteristics. JPV, KH, MCL, NA, SO, and JAN: performed data analysis and interpretation. JPV, KH, SAV, MCL, SO, and JAN: drafted the manuscript. All authors contributed to editing and critical revision for important intellectual contents.

Funding This work was supported by US National Institutes of Health (NIH) grants (P01 CA87969 to M J Stampfer; UM1 CA186107 to M J Stampfer; P01 CA55075 to W C Willett; UM1 CA167552 to W C Willett; U01 CA167552 to W C Willett and 
L A Mucci; P50 CA127003 to CSF; R01 CA118553 to CSF; R01 CA169141 to CSF; R01 CA137178 to ATC; K24 DK098311 to ATC; R35 CA197735 to S0; R01 CA151993 to S0; R01 CA248857 to S0, U Peters, and A I Phipps; K07 CA190673 to RN; R03 CA197879 to KW; R21 CA222940 to KW and MG; R21 CA230873 to KW and S0; and K07 CA188126 to XZ); by Nodal Award (2016-02) from the DanaFarber Harvard Cancer Center (to S0); by the Stand Up to Cancer Colorectal Cancer Dream Team Translational Research Grant (SU2C-AACR-DT22-17 to CSF and MG), administered by the American Association for Cancer Research, a scientific partner of SU2C; and by grants from the Project P Fund, The Friends of the Dana-Farber Cancer Institute, Bennett Family Fund, and the Entertainment Industry Foundation through National Colorectal Cancer Research Alliance. KH was supported by fellowship grants from the Uehara Memorial Foundation and the Mitsukoshi Health and Welfare Foundation. SAV was supported by grants from the Finnish Cultural Foundation and Orion Research Foundation. JB was supported by a grant from the Australia Awards-Endeavour Scholarships and Fellowships Program. KF was supported by a fellowship grant from the Uehara Memorial Foundation. KA was supported by grants from Overseas Research Fellowship from Japan Society for the Promotion of Science (JP201860083). KW was supported by an Investigator Initiated Grant from the American Institute for Cancer Research. ATC is a Stuart and Suzanne Steele MGH Research Scholar. JAM research is supported by the Douglas Gray Woodruff Chair fund, the Guo Shu Shi Fund, Anonymous Family Fund for Innovations in Colorectal Cancer, Project P fund, and the George Stone Family Foundation. MG was supported by a Conquer Cancer Foundation of ASCO Career Development Award.

Disclaimer The content is solely the responsibility of the authors and does not necessarily represent the official views of NIH. The funders had no role in study design, data collection and analysis, decision to publish, or preparation of the manuscript.

Competing interests SAV reports grants from Finnish Cultural Foundation and Orion Research Foundation sr during the conduct of the study. KF reports other from Uehera Memorial Foundation (overseas scholarship) during the conduct of the study. ATC reports grants and personal fees from Bayer Pharma AG and personal fees from Pfizer Inc. and Boehringer Ingelheim outside the submitted work. RN is currently an employee and shareholder of Pfizer Inc. She contributed to this study before she was employed by Pfizer Inc. CSF reports consulting role for Agios, Amylin Pharmaceuticals, Astra-Zeneca, Bain Capital, CytomX Therapeutics, Daiichi-Sankyo, Eli Lilly, Entrinsic Health, Evolveimmune Therapeutics, Genentech, Merck, Taiho, and Unum Therapeutics; he also serves as a Director for CytomX Therapeutics and owns unexercised stock options for CytomX and Entrinsic Health; he is a cofounder of Evolveimmune Therapeutics and has equity in this private company; he has provided expert testimony for Amylin Pharmaceuticals and Eli Lilly. JAM reports personal fees from COTA Healthcare and Taiho Pharmaceutical (for NCCN Grant Review Panel) outside the submitted work. MG reports grants from Bristol-Myers Squibb, Merck, and Servier outside the submitted work. JAN reports grants from NanoString and Illumina outside the submitted work. The other authors declare that they have no conflicts of interest.

Patient and public involvement statement Patients or the public were not involved in the design, or conduct, or reporting, or dissemination plans of this research.

Patient consent for publication Not required.

Ethics approval The study protocol was approved by the institutional review boards of the Brigham and Women's Hospital and Harvard T.H. Chan School of Public Health (Boston, Massachusetts, USA), and those of participating registries as required. Written informed consent was obtained from all participants.

Provenance and peer review Not commissioned; externally peer reviewed.

Data availability statement Data may be obtained from a third party and are not publicly available. The data underlying this article cannot be shared publicly. Further information including the procedures to obtain and access data from the Nurses' Health Studies and Health Professionals Follow-up Study are described at https:// www.nurseshealthstudy.org/researchers/ and https://sites.sph.harvard.edu/hpfs/ for-collaborators/.

Supplemental material This content has been supplied by the author(s). It has not been vetted by BMJ Publishing Group Limited (BMJ) and may not have been peer-reviewed. Any opinions or recommendations discussed are solely those of the author(s) and are not endorsed by BMJ. BMJ disclaims all liability and responsibility arising from any reliance placed on the content. Where the content includes any translated material, BMJ does not warrant the accuracy and reliability of the translations (including but not limited to local regulations, clinical guidelines, terminology, drug names and drug dosages), and is not responsible for any error and/or omissions arising from translation and adaptation or otherwise.

Open access This is an open access article distributed in accordance with the Creative Commons Attribution Non Commercial (CC BY-NC 4.0) license, which permits others to distribute, remix, adapt, build upon this work non-commercially, and license their derivative works on different terms, provided the original work is properly cited, appropriate credit is given, any changes made indicated, and the use is non-commercial. See http://creativecommons.org/licenses/by-nc/4.0/.

\section{ORCID iDs}

Juha P Väyrynen http://orcid.org/0000-0002-8683-2996

Jonathan A Nowak http://orcid.org/0000-0002-0943-7407

\section{REFERENCES}

1 Sung H, Ferlay J, Siegel RL, et al. Global cancer statistics 2020: GLOBOCAN estimates of incidence and mortality worldwide for 36 cancers in 185 countries. CA Cancer J Clin 2021. doi:10.3322/ caac.21660. [Epub ahead of print: 04 Feb 2021].

2 Kather JN, Halama N. Harnessing the innate immune system and local immunological microenvironment to treat colorectal cancer. $\mathrm{Br} \mathrm{J}$ Cancer 2019;120:871-82.

3 Murray PJ. Macrophage polarization. Annu Rev Physiol 2017;79:541-66.

4 Bronte V, Chappell DB, Apolloni E, et al. Unopposed production of granulocyte-macrophage colony-stimulating factor by tumors inhibits CD8+ T cell responses by dysregulating antigen-presenting cell maturation. J Immunol 1999;162:5728-37.

5 Gabrilovich D, Ishida T, Oyama T, et al. Vascular endothelial growth factor inhibits the development of dendritic cells and dramatically affects the differentiation of multiple hematopoietic lineages in vivo. Blood 1998;92:4150-66.

6 Bronte V, Brandau S, Chen S-H, et al. Recommendations for myeloid-derived suppressor cell nomenclature and characterization standards. Nat Commun 2016;7:12150.

7 Gabrilovich DI, Bronte V, Chen S-H, et al. The terminology issue for myeloid-derived suppressor cells. Cancer Res 2007;67:425.

8 Francisco-Cruz A, Parra ER, Tetzlaff MT, et al. Multiplex immunofluorescence assays. Methods Mol Biol 2020;2055:467-95.

9 Alexander PG, McMillan DC, Park JH. The local inflammatory response in colorectal cancer - Type, location or density? A systematic review and meta-analysis. Cancer Treat Rev 2020;83:101949.

10 Munder M. Arginase: an emerging key player in the mammalian immune system. Br J Pharmacol 2009;158:638-51.

11 Yamauchi M, Lochhead P, Morikawa T, et al. Colorectal cancer: a tale of two sides or a continuum? Gut 2012;61:794-7.

12 Ogino S, Kawasaki T, Brahmandam M, et al. Sensitive sequencing method for KRAS mutation detection by pyrosequencing. $\mathrm{J} \mathrm{Mol}$ Diagn 2005;7:413-21.

13 Ogino S, Kawasaki T, Kirkner GJ, et al. Evaluation of markers for CpG island methylator phenotype (CIMP) in colorectal cancer by a large population-based sample. J Mol Diagn 2007;9:305-14.

14 Ogino S, Kawasaki T, Nosho K, et al. LINE-1 hypomethylation is inversely associated with microsatellite instability and $\mathrm{CpG}$ island methylator phenotype in colorectal cancer. Int $\mathrm{J}$ Cancer 2008;122:2767-73.

15 Nosho K, Kawasaki T, Ohnishi M, et al. PIK3CA mutation in colorectal cancer: relationship with genetic and epigenetic alterations. Neoplasia 2008;10:534-41.

16 Giannakis M, Mu XJ, Shukla SA, et al. Genomic correlates of Immune-Cell infiltrates in colorectal carcinoma. Cell Rep 2016;15:857-65.

17 Haruki K, Kosumi K, Li P, et al. An integrated analysis of lymphocytic reaction, tumour molecular characteristics and patient survival in colorectal cancer. Br J Cancer 2020;122:1367-77.

18 Chan AT, Ogino S, Fuchs CS. Aspirin and the risk of colorectal cancer in relation to the expression of COX-2. N Engl J Med 2007;356:2131-42

19 Väyrynen JP, Lau MC, Haruki K, et al. Prognostic significance of immune cell populations identified by machine learning in colorectal cancer using routine hematoxylin and Eosin-Stained sections. Clin Cancer Res 2020;26:4326-38.

20 Tóth ZE, Mezey E. Simultaneous visualization of multiple antigens with tyramide signal amplification using antibodies from the same species. J Histochem Cytochem 2007;55:545-54.

21 Røge R, Nielsen S, Vyberg M. Carb-3 is the superior antiCD15 monoclonal antibody for immunohistochemistry. Appl Immunohistochem Mol Morphol 2014;22:449-58. 
22 Hoyer JD, Grogg KL, Hanson CA, et al. CD33 detection by immunohistochemistry in paraffin-embedded tissues: a new antibody shows excellent specificity and sensitivity for cells of myelomonocytic lineage. Am J Clin Pathol 2008;129:316-23.

23 Grüneberg U, Rich T, Roucard C, et al. Two widely used anti-DRo monoclonal antibodies bind to an intracellular C-terminal epitope. Hum Immunol 1997:53:34-8.

24 Koelzer VH, Canonica K, Dawson H, et al. Phenotyping of tumorassociated macrophages in colorectal cancer: impact on single cell invasion (tumor budding) and clinicopathological outcome. Oncoimmunology 2016;5:e1106677.

25 Rao H-L, Chen J-W, Li M, et al. Increased intratumoral neutrophil in colorectal carcinomas correlates closely with malignant phenotype and predicts patients' adverse prognosis. PLoS One 2012;7:e30806.

26 Governa V, Trella E, Mele V, et al. The interplay between neutrophils and $\mathrm{CD}^{+} \mathrm{T}$ cells improves survival in human colorectal cancer. Clin Cancer Res 2017;23:3847-58.

27 Forssell J, Oberg A, Henriksson ML, et al. High macrophage infiltration along the tumor front correlates with improved survival in colon cancer. Clin Cancer Res 2007;13:1472-9.

28 Fujiyoshi K, Bruford EA, Mroz P, et al. Opinion: standardizing gene product nomenclature-a call to action. Proc Natl Acad Sci U S A 2021;118:e2025207118.

29 Väyrynen JP, Haruki K, Lau MC, et al. The prognostic role of macrophage polarization in the colorectal cancer microenvironment. Cancer Immunol Res 2021;9:8-19.

30 Fujiyoshi K, Väyrynen JP, Borowsky J, et al. Tumour budding, poorly differentiated clusters, and T-cell response in colorectal cancer. EBioMedicine 2020;57:102860.

31 Parra ER, Uraoka N, Jiang $\mathrm{M}$, et al. Validation of multiplex immunofluorescence panels using multispectral microscopy for immune-profiling of formalin-fixed and paraffin-embedded human tumor tissues. Sci Rep 2017;7:13380.

32 Baddeley A, Turner R. spatstat : An $R$ Package for Analyzing Spatial Point Patterns. J Stat Softw 2005;12:282-90.

33 Barua S, Fang P, Sharma A, et al. Spatial interaction of tumor cells and regulatory $T$ cells correlates with survival in non-small cell lung cancer. Lung Cancer 2018;117:73-9.

34 Benjamin DJ, Berger JO, Johannesson M, et al. Redefine statistical significance. Nat Hum Behav 2018;2:6-10.

35 Liu L, Nevo D, Nishihara R, et al. Utility of inverse probability weighting in molecular pathological epidemiology. Eur J Epidemiol 2018;33:381-92.

36 Seaman SR, White IR. Review of inverse probability weighting for dealing with missing data. Stat Methods Med Res 2013;22:278-95.

37 Hamada T, Cao Y, Qian ZR, et al. Aspirin use and colorectal cancer survival according to tumor CD274 (programmed cell death 1 ligand 1) expression status. J Clin Oncol 2017;35:1836-44.

38 Grasso CS, Giannakis M, Wells DK, et al. Genetic mechanisms of immune evasion in colorectal cancer. Cancer Discov 2018;8:730-49.

39 Axelrod ML, Cook RS, Johnson DB, et al. Biological consequences of MHC-II expression by tumor cells in cancer. Clin Cancer Res 2019:25:2392-402

40 Laszlo GS, Estey EH, Walter RB. The past and future of CD33 as therapeutic target in acute myeloid leukemia. Blood Rev 2014;28:143-53.
41 Jiang W, Adler LN, Macmillan H, et al. Synergy between B cell receptor/antigen uptake and $\mathrm{MHCll}$ peptide editing relies on HLA-DO tuning. Sci Rep 2019;9:13877

42 Mengos AE, Gastineau DA, Gustafson MP. The CD14 ${ }^{+} \mathrm{HLA}$ $\mathrm{DR}^{\mathrm{lo} / \mathrm{neg}}$ monocyte: an immunosuppressive phenotype that restrains responses to cancer immunotherapy. Front Immunol 2019:10:1147.

43 Ibrahim ML, Klement JD, Lu C, et al. Myeloid-Derived suppressor cells produce IL-10 to elicit DNMT3b-Dependent IRF8 silencing to promote colitis-associated colon tumorigenesis. Cell Rep 2018;25:3036-46.

44 Gonzalez-Junca A, Driscoll KE, Pellicciotta I, et al. Autocrine TGF $\beta$ is a survival factor for monocytes and drives immunosuppressive lineage commitment. Cancer Immunol Res 2019;7:306-20.

45 Jaillon S, Ponzetta A, Di Mitri D, et al. Neutrophil diversity and plasticity in tumour progression and therapy. Nat Rev Cancer 2020;20:485-503.

46 De Palma M, Biziato D, Petrova TV. Microenvironmental regulation of tumour angiogenesis. Nat Rev Cancer 2017;17:457-74.

47 Álvaro-Benito M, Freund C. Revisiting nonclassical HLA II functions in antigen presentation: peptide editing and its modulation. HLA 2020;96:415-29.

48 Wikberg ML, Ling A, Li X, et al. Neutrophil infiltration is a favorable prognostic factor in early stages of colon cancer. Hum Pathol 2017;68:193-202.

49 Galdiero MR, Bianchi P, Grizzi F, et al. Occurrence and significance of tumor-associated neutrophils in patients with colorectal cancer. Int $J$ Cancer 2016;139:446-56.

50 Li Y-W, Qiu S-J, Fan J, et al. Intratumoral neutrophils: a poor prognostic factor for hepatocellular carcinoma following resection. $J$ Hepatol 2011;54:497-505.

51 Jensen HK, Donskov F, Marcussen N, et al. Presence of intratumoral neutrophils is an independent prognostic factor in localized renal cell carcinoma. J Clin Oncol 2009;27:4709-17.

52 Elliott LA, Doherty GA, Sheahan K, et al. Human tumor-infiltrating myeloid cells: phenotypic and functional diversity. Front Immunol 2017;8:86.

53 Jacobsen LC, Theilgaard-Mönch K, Christensen El, et al. Arginase 1 is expressed in myelocytes/metamyelocytes and localized in gelatinase granules of human neutrophils. Blood 2007;109:3084-7

54 Chen B, Alvarado DM, Iticovici M, et al. Interferon-Induced IDO1 mediates radiation resistance and is a therapeutic target in colorecta cancer. Cancer Immunol Res 2020;8:451-64.

55 Mestas J, Hughes CCW. Of mice and not men: differences between mouse and human immunology. J Immunol 2004;172:2731-8.

56 Ogino S, Nowak JA, Hamada T, et al. Insights into pathogenic interactions among environment, host, and tumor at the crossroads of molecular pathology and epidemiology. Annu Rev Pathol 2019;14:83-103.

57 Benson AB, Venook AP, Al-Hawary MM, et al. NCCN guidelines insights: colon cancer, version 2.2018. J Natl Compr Canc Netw 2018;16:359-69.

58 Pagès F, Mlecnik B, Marliot F, et al. International validation of the consensus immunoscore for the classification of colon cancer: a prognostic and accuracy study. Lancet 2018;391:2128-39. 